\title{
Making Modern Childhood, the Natural Way: Psychology, Mental Hygiene, and Progressive Education at Ontario Summer Camps, 1920-1955
}

\section{Sharon Yvonne Wall}

\begin{abstract}
In the first half of the twentieth century, summer camps in Ontario were promoted as a muchneeded escape from city living and the pathway to a world of natural, pre-modern simplicity. This paper demonstrates that, by the late 1920s, camp administrators and promoters were in fact, pulled in two directions; they treasured the idea of anti-modern escape, but, they also sought to make the camp programming "truly modern" by integrating the latest psychological and educational wisdom. At all sorts of camps, the language and aims of educational psychology and the mental hygiene movement influenced the nature of camp goals, camp programming, and thinking about campers themselves. Camp was regarded as providing the ideal environment for fostering psychological health and for applying the principles of progressive education. This paper explores administrators' views of the value of psychological and educational expertise, the extent to which they were able to apply these at camp, and, to a lesser extent, children's reactions to the modern, psychologized camp.
\end{abstract}

\section{RÉSUMÉ}

Durant la première demie du XXe siècle, les camps d'été de l'Ontario étaient présentés comme une évasion indispensable de la vie urbaine et comme la voie menant à un univers de simplicité naturelle, prémoderne. Ce texte montre que, à la fin des années 1920, les administrateurs et les promoteurs des camps étaient de fait partagés : ils chérissaient l'idée d'une évasion antimodernité, mais ils cherchaient aussi à instaurer des activités " franchement modernes ", en intégrant les dernières avancées psychologiques et éducatives. Dans les différents camps, le langage et les buts de la psychologie éducative et le mouvement d'hygiène mentale influencèrent les objectifs et les activités des camps ainsi que la réflexion portant sur les enfants eux-mêmes. Le camp était considéré comme environnement idéal pour la stimulation de la santé psychologique et l'application des principes d'une éducation nouvelle. Cet article examine la pensée des administrateurs sur la valeur de la compétence psychologique et éducative des camps; il montre jusqu'à quel point les administrateurs furent capables de l'appliquer dans les camps. L'article examine aussi, mais à un degré moindre, les réactions des enfants face à un camp moderne et "psychologique". 


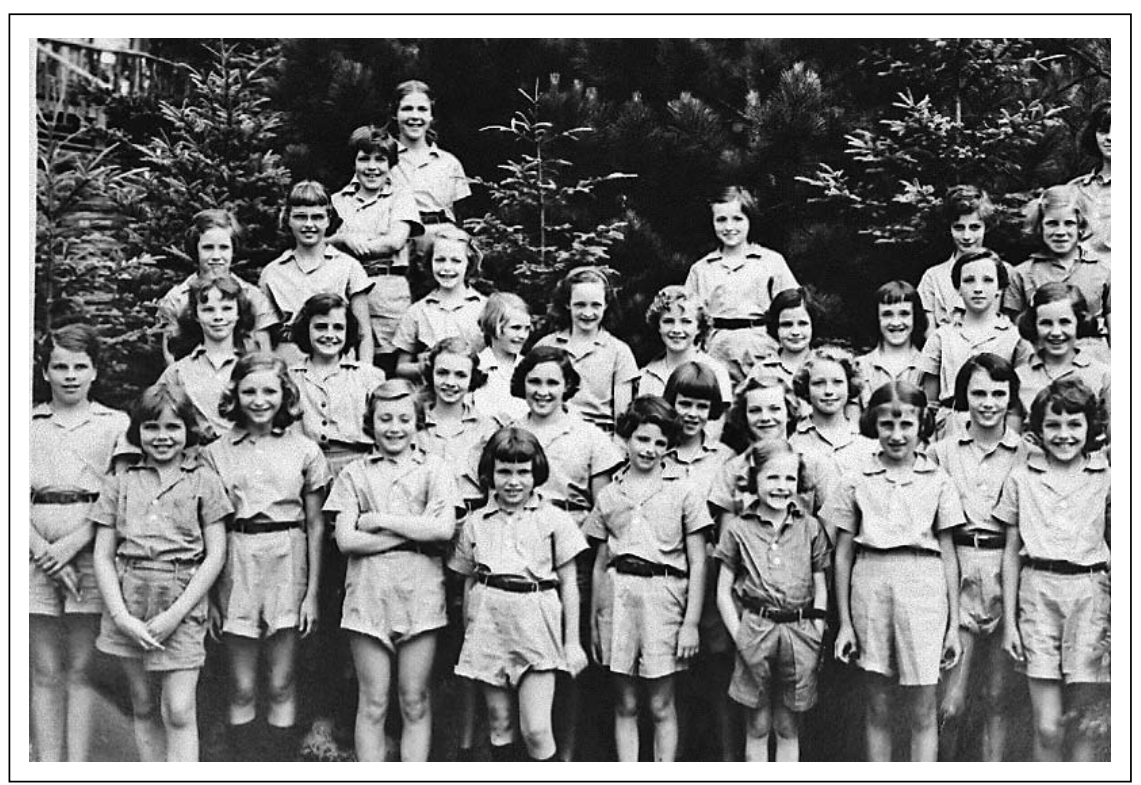

Campers at Camp Tanamakoon, c. 1930s. Algonquin Park Museum Archives \#3153 (George May).

In a radio broadcast of April 1947, Dr. J.G. Althouse, Ontario's Chief Director of Education, praised the summer camp for all it had to offer the children and youth of the province. In his comments he lauded the camp's natural setting, commended the simplicity of its programming, and extolled the old-fashioned self-sufficiency it engendered. In a sentence, he summed up what many regarded as the camp's most vital attribute. At summer camp, he explained, "The complications of our modern way of life are largely removed." ${ }^{1}$ In his understanding of camp life as offering a possible flight from modernity, Althouse was not alone. Camp administrators from the late 1920s through to the early postwar period promoted the summer camp as both a much-needed escape from modern, urban living and the pathway to a world of natural, pre-modern simplicity.

Idealizations such as these were meant to convince the public, but they shouldn't fool the historian as to the camp's very real implication in modernity. Summer camps were situated in the seemingly constant world of nature, but their administrators also prided themselves on keeping abreast of the most recent psychological and educational trends. While the notion that outdoor living was good for one dated back at least as far as the mid-nineteenth century, during the middle decades of the twentieth century, this idea was elaborated and refined by those influenced by the emerging discipline of psychology. During these years, promoters of camp life regarded it as providing the ideal environment for fostering psychological health and well-being. They also argued that the camp was unique in its ability not only to preach the ideals of progressive education, but, more importantly, to apply them.

In essence, the summer camp had a dual face. What many people saw when they looked at the camp was a retreat from the modern world. As social theorist, Anthony 
Giddens has argued, under conditions of modernity nature is typically "constituted independently of human social activity," allowing many to think of it (wrongly) as a world apart. ${ }^{2}$ Those who ran and administered camps sought to capitalize on, and often shared this perception, but they also saw the usefulness of bringing modernity to the backwoods. If "getting back to nature" had at least the air of good old-fashioned simplicity about it, when it came to thinking about "the child" who was to be transformed by this experience, summer camp openly declared itself part and parcel of a very modern project. For, as Giddens also argues, one of the defining features of modernity is that: "[e]xpert systems are not confined to areas of technological expertise. They extend to social relations themselves and to the intimacies of the self.... The doctor, counsellor and therapist are as central to the expert systems of modernity

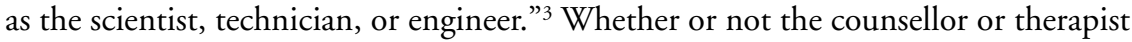
always achieved their desired ends in the natural setting of summer camp, as elsewhere, reliance on their expertise nonetheless marked a significant shift in systems of cultural authority.

This paper explores the impact of educational psychology and progressivism on the Ontario summer camp. As its source base, it relies on the records of a variety of camps across the province. One set of these were private camps founded by urban middle-class individuals, designed to turn a profit by serving an elite clientele. A second set were agency camps founded by groups like the YMCA, religious organizations like the Canadian Girls in Training (CGIT), and the Ontario government, all of which served a mainly middle-class (but also partly working-class) clientele. A third group were "fresh air" camps run by churches, charities and other non-profit organizations which offered subsidized camp holidays to the poorest sector of Ontario's working-class. Due to its prominence as the largest fresh air camp in the province, Bolton Camp, situated just outside Toronto, was chosen as a case study of the fresh air experience. These three types of camps represent a cross-section of the Ontario camp community during these years. An examination of their diverse settings reveals that, at all manner of camps, reliance on emerging psychological and educational expertise shaped thinking about the benefits of camp, about the nature of "the child," and about "childhood" as a category of experience. At the same time, the class background of campers shaped the application of psychological ideas in different ways at different Ontario camps as actual children were encountered and managed. As far as camps' educational missions were concerned, they were possibly more successful than schools in delivering progressive education, although there were also limits to the progressive experiment.

\section{Modern Theories in a Natural Setting}

The emergence of the summer camp took place amidst important changes in thinking concerning child development in North America. In the late nineteenth century, emerging notions of children as dependent and in need of protection resulted in the introduction of public and later, compulsory, schooling, the establishment of separate children's institutions, and struggles to eliminate child labour. ${ }^{4}$ Into the 
twentieth century, the modern notion of childhood that these changes implied was further bolstered by the force of scientific and professional expertise. Common sense understandings of children as living a distinct stage of the human experience were solidified by explicit theories of child development emanating from newly established departments of psychology. ${ }^{5}$

The emergence of psychology as a distinct discipline was closely tied with what was known, in North America, as the mental hygiene movement. National committees for the promotion of mental hygiene were established in both the U.S. and Canada in 1909 and 1918 respectively. ${ }^{6}$ It was these bodies that, as historian Mona Gleason puts it, "brought psychology out of the laboratory and into the public spaces." ${ }^{7} \mathrm{With}$ the help of funding from the Canadian body, the first Canadian Department of Psychology was established at the University of Toronto in $1926 .{ }^{8}$ Initially, the discipline, like the movement, endorsed a largely hereditarian view of mental deficiency, a stance which limited the scope for professional intervention. As hereditarian views were increasingly discredited, however, this situation changed. According to the new wisdom, personalities were not born - they were made. Imbued with modern optimism regarding improvement and perfectibility, psychologists now emphasized the importance of environment, and the child and the earliest environments of childhood became the focus of much psychological investigation. At the same time, a focus on "normal" child development replaced the older concentration on the pathological.

In Canada, one of the psychologists who became prominent in this period was Dr. William E. Blatz. In his work, Blatz drew on each of the two dominant trends in contemporary psychology, behaviourism and Freudianism, as would the summer camp itself. On the one hand, Blatz sought to counter the "inefficiency" of most family homes; at his Institute for Child Study, for instance, the day nursery incorporated the same habit-training, unbending routine and detailed record-keeping favoured by the behaviourists and much of contemporary child-rearing advice literature. ${ }^{9} \mathrm{We}$ should "take them all away if we could," was his comment on the advisability of removing children from the parental home, revealing, like American psychologist, John Watson, an unabashed confidence in the expert approach. ${ }^{10}$ On the other hand, Blatz was also influenced by Freudian ideals. He rejected the use of coercion of any kind, objected to interference with children's natural inclinations, and favoured "freechoice learning," as an important counterpart to daily habit-training. Widely known for his role in overseeing the upbringing of the Dionne quintuplets, Blatz was less well-known for his involvement with summer camps. For a time, during the interwar years, Blatz served as on-site psychologist at the two well-known private camps run by Taylor Statten in Algonquin Park. In 1942, his connection with camping was formally recognized when the Ontario section of the (then) American Camping Association enlisted him to deliver lectures and stimulate discussions with groups of counsellors. ${ }^{11}$ Blatz' research was clearly conducted within the context of a discipline dominated by the mental hygiene perspective. In particular, his work fit with what Hans Pols describes as "the natural history model" of child development research. Proponents of this model were doubtful as to the usefulness of laboratory-based research, arguing that this setting was artificial, foreign to the child and, thus, not likely 
to replicate the everyday behaviour that psychologists sought to observe. ${ }^{12}$

Just how "natural" the camp was thought to be was the crux of its appeal not only to modern psychologists, but to many North Americans. Indeed, summer camps were not unique to Ontario; they appeared in other Canadian provinces and proliferated throughout the New England and later, other states, as scholars are beginning to document. ${ }^{13}$ To most observers, Canadian or American, what was most striking however, about this recreational innovation was not its connection to modern-day psychological or educational theory, but its wonderfully natural setting, a view camps worked to promote. In contrast to early nineteenth-century views, camp literature constructed nature as an unquestionably positive and life-giving force, a realm to be sought out and embraced, never feared. The backdrop for this highly romantic view of nature was, of course, the population shift from countryside to city, which had occurred by these years. In Ontario, as early as 1921, the urban population already stood at 58 percent. By 1951 the number had risen to $72 .{ }^{14}$ As a predominantly urban society, many Ontarians now looked back longingly on a time of presumably closer connection to the natural world. If not seriously interested in re-visiting their pioneer days, modern urbanites yet sought ways to "reconnect" with the natural world. In this regard, summer camp was only one among many nature-based recreations that had been attracting the attention of urban Ontarians from the late nineteenth century onwards. ${ }^{15}$

Like promoters of other wilderness and nature-based experiences, administrators at private, agency and fresh air camps in Ontario worked to instill images of camp life as the healthy antithesis of modern urban living. In glossy promotional brochures and in the pages of staff manuals, they depicted contact with trees, grasses, lakes, and sunshine as the ideal context for physical, emotional and spiritual health. Private camp literature extolled camp for providing well-to-do youth with "fresh strength with every contact with Mother Earth," while Fresh Air Fund promoters insisted that, for working-class children, "a good dose of outdoors cures almost anything." 16 These were not simply recreational choices, the literature seemed to insist; affiliation with the natural world was a prerequisite for healthy human development. "Every child has an instinctive yearning to get back to the natural and to the simple fundamentals of the green earth," one promoter of fresh air camps asserted in the pages of the Toronto Star. Another described "the inner longing for the country" that presumably resided within every youthful soul. ${ }^{17}$ Summer camp, then, was no superfluous luxury. In Camp Ahmek's 1939 private camp counsellor handbook, the language of necessity was used to describe its origin:

If the camp had not been invented, we should now have to create it, such need there is today of the steadying offices of direct contact with the earth: the constancy of evening and morning, the sureness of brooks and tides, the firmly planted trees, the upholding hills. Is it not well for us all early to find a close relationship with the earth, our long home?....A camping experience may be valuable if it does nothing more than to help a child enjoy being a first-hand part of roads and trails, fire and water, sunrise and dusk. ${ }^{18}$ 
This belief in nature's powerful, yet subliminal influence was the backdrop against which all summer camp projects were launched. As Michael Smith concludes in the context of American summer camps, the idea of nature as inherently good for children had an amazing "durability" throughout the twentieth century. ${ }^{19}$ So also in Ontario; whatever the camp's goals, whether to shape upper- or working-class youth, to "toughen up" boys, or socialize girls, they were more likely to be achieved in a natural setting, so the thinking went. Nature, so it seemed, wiped children clean of negative influence, creating just the conditions for ambitious educators to imprint their new messages on the childish slate.

\section{"As Far Removed as a South Sea Island"}

William Blatz' appearance at summer camp was not something that would have made sense in the early years of Ontario's summer camp history. At the turn of the century, when the first camps in the province were being established, the camp was understood in different terms. Indeed, the common wisdom within the camping movement was that, before the 1930s, camp objectives were conceptualized from a primarily recreational perspective. Camp directors who felt that they had advanced beyond this early phase looked back on these early years as a time when camp was advocated primarily as good clean fun and not much more. ${ }^{20}$

According to this narrative, camp objectives became more sophisticated and "educational" in the inter-war years. Particularly from the 1930s onwards, the camping movement articulated its goals in the language of educational psychology. This was no accident; camp directors had both direct and indirect connection to educational circles and to the emerging psychological discipline. Taylor Statten, founder of Camps Ahmek and Wapomeo in the early 1920s, and perhaps the most prominent individual in Ontario camping, conducted a twenty-year career with the YMCA, first as Secretary of Boys' Work for the Toronto Y, and later as National Boys' Work Secretary. Statten became widely known in Canada as a captivating public speaker and for his part in the development of the Canadian Standard Efficiency Test (CSET) for adolescent boys. He was also brought on staff at Pickering College in the 1920s as "Director of Character Education" and, according to his biographer, as the first vocational guidance counsellor in Canada. ${ }^{21}$ Mary Hamilton, founder of Tanamakoon in Algonquin Park in 1925, was head of physical education and later, principal, at Toronto's Margaret Eaton School, a private institution which played an important role in providing female physical education teachers across Toronto in the interwar years. Perhaps even more so than other camp directors, Hamilton's founding of Tanamakoon was envisioned as an extension of her work at the school; uniquely, she added camp counsellor training to the school's physical education course and arranged for students of physical education to apply their skills as new counsellors at Tanamakoon during the summer. ${ }^{22}$ Finally, Dr. Mary Northway, among the first cohort of girls to attend summer camps in the 1920s, later became staff and finally, director of her own canoe-trip camp in the 1940s, while also pursuing an academic career in child psychology at the University of Toronto as one of the favoured 
doctoral students of William Blatz. ${ }^{23}$ These are just several examples; many more could be given to underscore the fact that the summer camp in Ontario was deeply connected to the world of education and academic psychology. ${ }^{24}$

Operating within these milieus, camp directors were influenced by the dominant educational psychology of their time. In particular, camp literature echoed psychology's focus on the environment, something which came easily in a context where uniqueness of setting was the primary selling point. Camp administrators of all types shared the belief that human beings were capable of change and that their environment was the key factor in effecting it. While proponents of mental hygiene were "dazzled by the school's potential" 25 as a site for the observation (and alteration) of child behaviour, outdoor educationalists were even more hopeful of the camp. Camp was not only a distinct place in the geographic sense, it was also considered to provide a fundamentally new environment, with all the connotations of experimentation and potential progress this conjured up. In this lay its power, as promoters agreed. In the literature of fresh air camps as early as 1924, poor working-class children were described as "building for the days to come under a very great handicap indeed. One word explains it all and that word is 'environment."' 26

Though camps catered to distinct portions of Ontario's youth, they shared an understanding of what made the camp environment so valuable: first, its fundamentally "natural" character, and second, its isolation. Isolation entailed not only distance from consumer culture, but also from competing educational influences, including the home. The authors of Camping and Character stated openly in 1929 that it was the setting in which "erratic parental discipline can be avoided and ... mental hygiene methods ... carried out without prejudice or interference." ${ }^{27}$ Clearly, when seen in light of the psychological aims of the movement, this physical removal took on added importance. Isolation was what every psychologist sought, the necessary condition for the controlled experiment. For those who favoured the natural history model, camp seemed to offer a nice balance of the two. Without placing children in the artificial laboratory setting, camp founders created the conditions for "a constancy and thoroughness of observation ... which cannot be secured in many other situations," as Camping and Character recognized. "In camp ... the entire day may be carefully observed and recorded." ${ }^{28}$ Psychologist and camp director Mary Northway, elaborated on the camp's usefulness for child study in 1940:

The summer camp offers an ideal field for research for the social psychologist. It is an isolated, constant, temporary group, as far removed from the ordinary roads of social intercourse as a south sea island. Camp suddenly comes into existence when a group of individuals, cut off from the ties of their normal societies, are thrust together in one geographic community, and a new society is created. While camp lasts, it is an isolated community; and it may be considered a society in miniature. ${ }^{29}$

It would be a mistake however, to see the two essential aspects of the camp environment-nature and isolation - as unrelated. As camp educators saw it, it was 
precisely the combination of the two which made the camp superior to other children's institutions. Camp isolated children more completely than either schools or clinics. And yet, while the camp seemed to offer "complete environmental control," it was also thought to present opportunities for "personal fulfilment of emotions and interests." ${ }^{30}$ In short, camp was meant to be both fun and psychologically beneficial. According to a 1933 report from Bolton (fresh air) Camp, in terms of fostering healthy "self-development," camp offered children, "greater opportunity ... than if they were at the most expensive Summer Hotels." ${ }^{31}$ The clear implication was that "over-civilized" luxury and comfort prevented honest connection with the natural world. Summer camp, by contrast, offered life-changing experiences of direct contact with nature. The healthiest modern children, then, would be shaped in this seemingly pre-modern setting.

One of the qualities camps were praised for fostering was independence, something Blatz and his contemporaries saw as a key marker of maturity. In effect, camp was to act as a way station between childhood and adulthood, a space in which children could achieve "emancipation" from parents. Especially at private camps where children, sometimes as young as four years old, spent the eight weeks of summer, increased independence was an inevitable by-product. As Camp Ahmek's counsellor handbook explained in 1939, "'Untying apron strings' is a popular way - [and, clearly, also a gendered one] — of expressing this function. This process of emotional weaning and the establishment of habits of independence ... must be complete before an individual has achieved psychological adulthood. Even in a month or two, the camp can frequently accomplish very valuable results in helping campers to 'grow up." " 32 In this same spirit, the Camp Ahmek administration discouraged counsellors from demanding "blind obedience to authority" from their campers. ${ }^{33}$ Camp was meant to build confidence, helping children to think for themselves and stand on their own feet. As in the wider world of psychology, shy children were regarded as in particular need of improvement. Staff were instructed to use "careful observation" to root out the "timid or seclusive[sic]" camper, while camp bulletins glowed with reports of "happier and more self-confident" children of those previously "quiet and withdrawn." 34

At camp, as elsewhere, the ultimate test of the healthy personality was the ability to work well with others and especially one's peers. Though clearly ordered by adults, camp was regarded as a world made for children, a mini-community in which their needs were paramount and in which they were to learn, above all, from each other. There, children neglected, coddled, or perhaps without siblings at home were forced to live alongside others on an on-going basis, a matter for praise in the camp literature. Mary Northway stressed in 1939: "It is highly important that a child learn to be at home with his own contemporaries. Acceptability by older people or by younger children in no way makes up for failure to get along with one's own age group." 35 This focus on "peers," what historian Howard Chudacoff describes as an emerging "age consciousness," was echoed throughout the camp movement. ${ }^{36}$ On a practical level, age grouping of campers became pedagogical imperative. It was clearly with pride that a 1938 report stated, "The programme of Bolton Camp has grown by 
studying the needs of each age and sex group and planning for these accordingly." ${ }^{37} \mathrm{~A}$ year later the camp had divided children ranging from infants to sixteen years into at least six separate categories, each with its own distinct programme, a pattern repeated at private and agency camps of this period. ${ }^{38}$

Typically, peers were understood to be children of the same age; at summer camp, peers were also grouped by class. While a degree of overlap always existed, generally speaking, camps of different types were established for children from different economic backgrounds, a reality which also shaped the nature of psychology's impact at camp. At private camps with typically hefty fees, resources were available to hire onsite psychologists and to undertake extensive psychological testing. Lower camperto-staff ratios also allowed counsellors and other staff to pay more careful attention to individual campers and to apply principles of child psychology to their work. ${ }^{39}$ Parents of these middle- and upper-class campers might also have played a role. In the inter-war years, parents of this sort were more likely to seek out the camp for its socializing potential than, say, parents of the poor, who appreciated fresh air camps mainly for providing out-of-city holidays and a break for overworked mothers. As early as the 1920s, Camp Ahmek administrators were aware that well-to-do parents sent children to them so that they would "learn to play and become less reserved," "to gain more self confidence and overcome shyness" and "one of the most common suggestions," to learn to "mix readily with others." ${ }^{40}$ More cynical opinions suggested these wealthy parents also appreciated having children off their hands for the summer, but likely they also expected them to come home better people. ${ }^{41}$

In a number of cases, private camp directors and staff were, themselves, trained psychologists who looked to the world of camping as a summertime outlet for their expertise. The case of Mary Northway has already been mentioned here. Her accomplished academic career, in fact, drew on her lifelong interest in camping. Her doctoral research was a case study of children's social relationships at camp, researched at Glen Bernard, the camp of her own childhood and youth. Upon completion of her dissertation in 1938, Blatz took her on as lecturer at the prestigious Institute of Child Study. Northway's training clearly influenced her approach to campers, for instance, her Watsonian belief that she was working with "the most powerful and plastic material in the world, namely, children." ${ }^{42}$ In her eyes, good camp workers were produced by combining experience with children and "technical knowledge of child development." Elsie Palter provides another example of a trained psychologist turned camp director. After founding Camp Kawagama with her husband in 1945, she prided herself on keeping a psychological profile of every camper who passed through the camp gates. With a box of index cards kept well into old age, Palter was apparently still analyzing her campers many years after their camp holidays. ${ }^{43}$

Of all private camps in Ontario, Camp Ahmek stands out for its early, most intensive and thorough-going application of psychology to the realm of camping. Indeed, one might regard the Ahmek administration as one of the "early adopters" of ideas that would become widely accepted elsewhere in later years. ${ }^{44}$ Established by Taylor Statten in 1921 on the shores of Canoe Lake in the southwestern corner of Algonquin Park, Ahmek was located so as to attract the interest of the wealthier 
classes. It also attracted the interest of two social scientists, Hedley S. Dimock and Charles E. Hendry, who undertook observational studies at the camp, resulting in a number of publications over the years.

The most widely-read of these publications was Camping and Character, what some would come to think of as the "North American bible of camping." Ultimately, the (over three hundred page) 1929 study amounted to the camp's public statement on the fruitful union of psychology, education and camping and was tellingly subtitled "An Experiment in Character Education." While admitting to difficulties in the precise measurement of "character," the authors nonetheless expounded on the importance of applying "the most rigourous scrutiny and techniques" asserting, "the summer camp must participate in th[e] endeavor to develop and apply more scientific methods to test its results." Indeed, in a chapter on "Appraising the Results," life at camp read like a formal psychology experiment, complete with references to "measuring devices," "empirical judgements," and "standard deviations," replete with charts and graphs. ${ }^{45}$

Dimock and Hendry gathered information for their study in a number of ways. First, there were the medical exams, two or three "tests of proficiency" in camping skills, and other tests assessing campers' general intelligence, knowledge and values. More covertly, counsellors rated campers according to the camp's "Behaviour Frequency Rating Scale" which included fifty-four different aspects of behaviour. Children were also the subject of more descriptive "behaviour observation reports," and "weekly progress reports" on their general conduct and camping skills. Finally, parents were asked to assess their child's social, emotional, and psychological progress before and after camp, another way of furthering the parent education goals of mental hygiene. ${ }^{46}$ Clearly, record-keeping and analysis were central to this project. The camp's counselling handbook stated in 1939, "In the business world records and accounting as a means of judging results are taken for granted. Because the camp is not dealing with tangible outcomes, such as automobiles or biscuits, for example, is no reason for not attempting some accounting of results. We believe that persons and their development are of great importance, worthy of adequate records, and of the best techniques of appraisal." ${ }^{47}$ What solidified and further facilitated psychology's impact at Ahmek was the establishment of the camp's own "Department of Psychology" in 1930. Like the many child guidance clinics springing up across North American cities after World War I, the Department allowed a set of bona fide professionals to hone their strategies for the measurement and recording of psychological data at camp. ${ }^{48}$

What sort of "character," one might wonder, did these professionals set out to measure? The list of items on the "Behaviour Observation Scale" gave some indication. Rather than the older nineteenth-century focus on sobriety, thrift, and Sabbathobservance, or on a list of "immoral" habits, the scale aimed at detecting defective personalities and indications of "maladjustment." Counsellors were expected to rate campers in terms of "resourcefulness," "initiative," "leadership" and "friendliness," as well as 'stubbornness," "timidity", "fearfulness," and "overbearing attitude." While "character" could be detected in such things as the willingness "to observe rules and 
regulations" and to "contribute well-considered suggestions to the ... group," lack of adjustment was apparent in tendencies to "blush easily," to "grouch [and] find fault," and to "seek the limelight." In essence, character and well-adapted personalities were one and the same. Both were now matters of near-scientific dimensions, as the camp's interest in decoding "laws of personality" suggested. With their focus on the child's "fundamental urges, drives or motives," such laws implied, as many psychologists were doing, that there were really no "bad" children, simply those who used maladaptive means to achieve their emotional ends. ${ }^{49}$

Ultimately the "psychological gaze" at Ahmek was broad indeed. The typical child was evaluated and assessed at every turn, whether by formal testing or simply while enjoying the life of camp. In addition, more difficult, misbehaving youth could expect individual visits to the camp psychologist, a scenario which allowed the gaze to become even more personal and direct. Camping and Character provided an overview of a few of these "problem campers," with behavioural problems such as "lying," "stealing," "temper tantrums," and "poor eating habits." At Ahmek's Psychology Department, camp psychologists observed, diagnosed, and treated them as they saw fit. In the course of this process, every problem and personality was refracted through the prism of psychological expertise. "During the interview with the psychologist," it was noted of one camper diagnosed "neurotic," "Albert was chewing gum, biting his nails, scratching, and constantly moving around. His fears included water, snakes, the dark, and lions. He dreams ... about spooky things.... Bed-wetting persisted until he was seven. When made to hold his hands quietly in his lap, his facial muscles were affected, indicating the definiteness of his neurotic condition." ${ }^{50}$ Clearly, what many might consider typical childhood habits and fears could be cause for professional intervention and treatment at the hands of psychological experts.

At Ahmek and other private camps, administrators developed a psychological critique not only of their campers, but also of the well-to-do family and home life. While private campers were frequently viewed as the leaders and up-standing citizens of the future, administrators also worried about the potential problems inherent in conditions of privilege. Here, camp psychologists anticipated the negative assessment of the wealthy family offered by Crestwood Heights authors in postwar years. ${ }^{51}$ In Camping and Character the case was made that material abundance posed its own unique challenges to healthy development:

The boys who attend private camps come largely from the homes of the business and professional classes. Their adjustment needs probably differ from the adaptive needs of boys in other kinds of camps... This does not imply for a moment that boys who come to private camps are better adjusted socially than the attendants at other camps. A parent's fortune may be a boy's greatest misfortune as has been repeatedly pointed out by psychiatrists. ${ }^{52}$

Put another way, "spoiling" was regarded as the ever-present danger in privileged families. Mary Northway's observations at Glen Bernard might have been made in many other private camp settings. She commented in 1937: "Bella was the youngest 
of six in a wealthy family. Very early she assumed the role of 'spoilt youngest' and used it to rule the family and gain her own ends.... She loved attention and used subtle tricks to secure it." ${ }^{53}$ This type of indulgence, many agreed, was leading to the "postponing of independence" and the development of undisciplined personalities, unfit for leadership roles. ${ }^{54}$

Overall, wealthy parents were accused of giving too much in a material sense, but when it came to the question of proper love and attention, they were often faulted with a lack of generosity. In Camping and Character, absentee parents drew special attention. Mothers, in particular, were charged with neglect of their duties, too often leaving children in the hands of alternate care-givers. In the case of "problem camper Ezekiel" it was stated, "His crudeness of dress and eating habits are largely accounted for by his home situation, where the responsibility is divided between the mother, maids, and a sister. This probably means that he does just about whatever he wants." Another mother who came in for criticism was described as "a woman of culture... away from home considerably," and who was in the habit of leaving her boys with either the housekeeper or their grandmother. Wealthy fathers, for their part, were blamed for being overly absorbed in business success and in out-of-town travel, and for giving children poor role models in their pursuit of social prestige. Clearly, while historians have told us much about professional critiques of the working-class family, it is interesting to note that, under psychology's gaze, wealthy families also came in for criticism. ${ }^{55}$

As the objects of this intensifying gaze, children at private camps responded in various ways. Reactions to on-site psychologists were sometimes distinctly negative. In this respect, the experts at Ahmek encountered some challenging cases, campers like "Freddy" who left his psychological assessment "in a humiliated ... but rebellious mood" and "Ezekiel," who, only hours after his session to improve his attitude was found "flick[ing] a large sticky piece of chewing gum into the camp mother's coiffure." ${ }^{56}$ Even those not in any way singled out for observation sometimes bristled at the psychologist's presence. Indeed, while completing their field-work, the authors of Camping and Character were felt, by some, to be hindering children's full enjoyment of camp. "[T]he two men 'got in the way' of campers doing their daily activities," states one history of the camp. "There were forms to be filled out and evaluations to be made every day which interrupted the normal flow of the programme. From a campers' point of view, the two men were 'outsiders' and did not appear to be the type of people to easily fit into a camp situation." ${ }^{57}$ Such responses were not entirely unique. At Glen Bernard, Mary Northway was forced to admit that her own research met with some resistance, despite her personal history with the camp. During the second phase of her research, she confessed there were several campers who refused to participate, indicating that the questions were "too personal." Asking participants to identify their "least favourite camper," for instance, generated "considerable resentment." 58 On the other hand, some campers who had trouble fitting in sometimes appreciated the individual attention of the professionals. ${ }^{59}$ The important point here is not so much whether the expert gaze was appreciated or not, but that it provided the template by which mental health or un-health was assessed, a very different scenario 
from that which prevailed just a few decades previously.

At agency camps run by youth organizations and religious groups, psychology also had its influence. Due to their relatively low fees, these camps did not have the resources to develop departments of psychology, but camper populations were small enough to allow for a fair bit of individual attention. At the YMCA's Camp Pine Crest, this translated in 1940 into "hundreds of hours" of "personal counselling," provided not by trained psychologists, but, nonetheless, by counsellors and, in some cases, the director. Administrators showed great faith in the value of this talk therapy, with camp reports detailing the progress of individual campers upon receiving the personalized attention of staff. ${ }^{60}$ Campers were praised for learning to share in cabin clean-up, for accepting an outcast camper, or just generally, for getting along with others. Administrators at agency camps, like those at private camps, stressed the importance of detailed record keeping as a way of counting their successes (or failures). As at Ahmek, information for records was solicited from parents, counsellors and other staff. At the Y's Tapawingo for girls, in 1951, at least some campers went through extensive "intake interviews" which included questions about parentchild relationships, children's work habits and interests, as well as attitudes towards "race and religious prejudice, snobbishness, ... boys, and sex." ${ }^{61}$ Administrators were self-conscious, like other camps, of how they differed from camps of the past in this regard. As a brief history of the Y's On-Da-Da-Waks put it somewhat smugly, "Record-keeping was not a strong point with the early directors of Camp O." ${ }^{62}$ By contrast, Pine Crest's administration was asserting, by 1949 that, "records are invaluable in estimating the success and value of camp programme and should therefore be very carefully kept." ${ }^{63}$ At the same time, these camps tried to balance Watsonian-style record keeping with a more Freudian interest in the individual child. Canoe trips, for instance, were to be planned "to fit the campers," while those keeping reports on the camp were expected to remember that "the most vital part of a camp concerned [the] boys, and what effect the camp had on their lives." ${ }^{64}$

This situation was both similar and different at fresh air camps in the province. Certainly, there was no question of on-site psychologists or departments of psychology at camps of this sort. Even if the hiring of professionals had been feasible (which it was not), with thousands of campers each summer (compared to, perhaps, two hundred at the typical private or agency camp), it would have required a small army of psychologists to offer the same level of attention. Furthermore, the short ten- to twelve-day stays typical at such camps allowed little time for observation, let alone diagnosis and treatment. Finally, one wonders to what degree psychological assessment was thought appropriate for working-class children. The actions of misbehaving poor children - boys in particular - did not go unnoticed, but were more likely to win them the label of delinquent, rather than neurotic, with the goal being to "reform" them at the hand of social workers rather than to "treat" them at the hand of psychologists.

Still, even at the low-budget, charity-run Bolton Fresh Air Camp, psychological theories had their impact and these years saw an increasing interest in campers' emotional and psychological well-being. While fresh air camps had initially recommended 
themselves to the public for their health benefits, concerted efforts were made in the late 1930s to convince the public that their mandate went far beyond providing nutrition and combating disease. "In terms of physical health [a camp holiday] means much," it was declared as early as 1931, "but no one will ever be able to estimate the benefits to mental health this outing ... means." ${ }^{65}$ Though camp promoters were not the first to make such claims, their emphasis on using nature as a tool in early personality development, rather than simply as a fresh air tonic, was unique. By 1944 administrators at Bolton declared that physical well-being was now taking a back seat to other concerns, that, in fact, "the health influences ... although very important in themselves, are subordinate in value to ... other factors." 66

Ultimately, camps of all types contributed to the broader cultural transformation of the meaning of childhood. Crucial to this way of thinking was that children were not just smaller versions of adult psyches. "Children are neither vegetables nor miniature men," Mary Northway asserted in 1939, while of director, Mary Edgar, it was said, "she felt very strongly that children should be children." ${ }^{67}$ These seemingly banal statements spoke volumes concerning the shift in conceptions of childhood. They highlighted the notion that children had needs, interests, and abilities distinct from those of adults, beliefs not so firmly held by previous generations.

In theory then, childhood was constructed as a category beyond class. Thus, while adults who enjoyed material comforts and holiday pleasures were to count themselves "lucky," all children were understood to be "deserving" of their rightful portion of good times. In this modern view, the condition of childhood denoted not only satisfaction of needs, but also the creation of good memories. Childhood was a time not only to be happy, but one to look back on with fondness, much as an idealized conflict-free past figured in anti-modernist thinking about collective experience. Childhood was to function as "the good old days" of every individual, the time before "now" when all was placid stability and calm. Again, compared with the outlook of earlier generations, this signalled a paradigm shift of somewhat radical proportions.

\section{Psychology and the Camp in Depression, War and Cold War}

Psychology impacted the summer camp throughout this period, but time also played a role in influencing the nature of its impact. The idea of camp as isolated from the rest of society, though never wholly true at any time, was shown to be even less so in the years of worldwide depression and war. The hard times of the 1930s for instance, had distinct, if varying, effect on camps in Ontario; private camps saw their enrolments drop, while fresh air camps felt increasing pressure to accommodate children from needy families. ${ }^{68}$ During World War II, state-organized mass mobilization of labour, resources and funds devoted to the war effort all had their impact, the most significant results being labour shortages and the challenges of fund-raising. ${ }^{69}$ Along with these, the imperative to ration, conserve, and contribute to the war effort shaped camp programming. Finally, the general affluence of the post-war period altered thinking about recreation and leisure and also made camp holidays accessible to many more Canadians. 
In each of these periods, apart from these general impacts, ideas about the psychology of camping were also affected. For its part, the Depression seemed to deepen the feeling that camp could offer escape from society, with the presumed isolation of camp life and its psychological benefits taking on added appeal. Bolton Camp saw its work as "still more essential and valuable," offering mothers and children a short respite from the strain of constant worry and daily troubles. In triumphant tone, a 1933 report declared the camp as "one area exempt from the Depression":

I do not mean that the finances were not affected....Quite the reverse. There had to be a concentration upon financial problems never before known. ... But all this was not apparent in the life of the Camp. As one entered its gates, that oppression and mental worry which have been universal for four years seemed to be left behind. The mothers and children coming from families which have known more than their share of these problems and worries became conscious that this was an area where, for a brief time at least, they could feel security and peace and happiness. ${ }^{70}$

Private camps also spoke of being isolated from the Depression at camp; however, for those who lived their whole lives isolated from real economic insecurity, these statements could take on an air of complacency. One camper, looking back on the 1930s at Ahmek, sounded almost smug about how easily the troubles of the world could be forgotten at camp. "I never felt in those days ... that the camp ever suffered from the Depression. You never had the feeling that the world was down, down, down. Once you hit Canoe Lake ... we[sic] were all having the greatest time in the world, the outside world was shut off and camp carried on in a very upbeat situation." ${ }^{71}$ As positive as such experiences must have been for young campers, the comforts (and potential mental health benefits) of such camps were accessible to only a privileged few, even in good times, and even more so during the Depression.

World War II presented camp administrators with different challenges. Though steering poor children away from criminal activities had always been a concern of fresh air camp promoters, it was in the war years, and immediately after, that references to juvenile delinquency increased. These concerns fit with what has already been documented about worries over family life during wartime, especially the perceived connection between married women's paid labour and increasing rates of juvenile delinquency. Camp literature and fund-raising appeals showed similar concern for absent fathers and mothers "exhausted by factory work." The children were the real concern, too often, it was said, packed into "crowded day nurseries" or, worse, left unattended and "roaming the streets." As was typical of the period, "delinquency" encompassed a range of behaviours, from petty thefts at outdoor fruit stalls and toy stores to the even more innocuous "crimes" of using "bad language" and, in one case, swimming nude at the Toronto Beaches. (Luckily, in this 1947 case, a "policeman of understanding" passed this "delinquent" on to the Toronto Star's Fresh Air Fund and not the juvenile court.) Although poverty and material conditions were sometimes alluded to in terms of causes, "summer boredom" was also blamed. Assuming 
that being deprived of outdoor fun was reason enough for delinquent behaviour, the Toronto Star reporter stated in August 1941, "Naturally, they can't go out and play golf, they don't play tennis, the lakefront often is weary miles away and they may not have a swimming suit. They can't get jobs, these youngsters, so they steal." 72 At camp, it was assumed these potential delinquents would make "fine contacts," form "new interests" and catch glimpses of "a better way of living" that would set them on the right path. ${ }^{73}$

While fresh air camps focused on the trouble working-class children might be causing around them, private camps gave more thought to the war's potentially harmful psychological effect on campers themselves. At the Taylor Statten camps, the war strengthened the citizenship-building mandate, but also caused debate over whether impressionable young minds should be exposed to the realities of military conflict. In response to a student questionnaire of 1942, Adele Ebbs (daughter of Taylor Statten and heavily involved in his camp enterprise), initially emphasized that "camp should not be isolated as Utopia from world events....[Campers] do have to return to their own communities ... and one of our main aims is to make them better citizens." ${ }^{74}$ Still, when asked directly if she believed in supplying campers with regular updates of current events, her answer was "No." Her real objection seemed to lie with the psychology of the matter. "[T] he issue can be over-emphasized if care is not taken," Ebbs explained, arguing that children could be "easily over-stimulated." Ultimately, she sought to instill practices of good citizenship among campers, to contribute to the war effort, but only if "keeping the emotional side under control." This all fit well with the notion of childhood as a protected time, the idea that "children should be children," and that certain types of knowledge were not suitable for their consumption. Still, camps differed on the question. Shirley Ford remembers director Mary Edgar reading out headlines and short articles on war news at Glen Bernard, suggesting that ideas were not uniform as to the information with which children could be expected to cope. ${ }^{75}$

As the world seemed an increasingly changing and unpredictable place in these years of Depression, war and, later, the Cold War, camp was looked to as a place to provide children with the sense of security that urban life, presumably, could not. Mary Northway paid special attention to fostering children's sense of security at camp. In a 1942 article entitled, "Security Pegs for Campers," she explained, "The good ground for security which camping offers ... is the fact that its very centre is life in the out-of-doors. As the child comes to know the law, order and beauty of the physical world ... he discovers a sense of permanency." By the very way in which nature was defined - in contrast to human life, so constant and never-changing - it seemed to promise the stability deemed lacking in the urban environment of impermanence and flux. In the same article, Northway offered that security was fostered by the hard work of camping. Indeed, she claimed, "camp is wrongly called simple":

It is not nearly so simple to collect wood, bring it in, pile it, light it and make it continue to flame, as it is to turn an electric switch on a city range; it is not nearly so simple to build a shelter to protect one from the rain as it is to unlock 
one's own front door. But for anyone who has discovered he can satisfy his own basic life needs through the work of his own mind and his own hands, the discovery gives a security that has permanent effect. ${ }^{76}$

In post-war years, fostering security was deemed no less - and perhaps more - important at camp, as it was in the political, economic and domestic realms. At the level of childhood, fostering security now meant more than just the filling of material needs; providing children with positive experiences was also crucial. Under the influence of Freudian thinking, popularized during the post-war years, childhood experiences were understood to have lasting importance. In 1949, a Fresh Air Fund appeal posed the rhetorical question, "How much of later success in life has its roots in childhood!" ${ }^{77}$ As if in response, a private camp brochure stated unequivocally in 1950, "The happiest adults are those who had happy and fruitful childhood experiences." 78 Starting from such premises, camps saw themselves providing not only happy experiences for young campers, but also lifelong emotional and psychological stability.

Once at camp, campers of the 1950s were subject to administrators with increasingly psychological aims. One place this was apparent was in the pages of camp manuals, where the language was increasingly psychologized. In 1950 at Ahmek, it was argued that children should use arts and crafts projects "to express their innermost feelings," while a CGIT camp manual of the same year advised using sports - "especially those using balls" — as a way of "releasing hostility." 79 In other post-war camp literature, the canoe trip was lauded for fostering not only "self-reliance" and "initiative," but also a facility with "co-operation" and a sense of "responsibility" for one's fellow camper. ${ }^{80}$ Staff, too, were being trained to think about their campers using psychological concepts and terms. Literature from the privately-run Camp Winnebagoe declared in 1946, "A thorough knowledge of child psychology is imperative in order to analyse the mental attitude of every camper." ${ }^{81}$ At the province's Bark Lake Camp for counsellors-in-training, the eight-hour course in "Understanding the Camper" contained all the staples of post-war thinking regarding permissive child-rearing and the "basic needs of the individual," such as the need for "self-respect," for "success," "dominance," and "new experiences." ${ }^{82}$ Even religiously-oriented camps were incorporating insights of more secular experts. The post-war CGIT counsellor was advised to "read some recommended materials on the psychology of adolescents," and to attempt to discover "what makes her [camper] tick." ${ }^{83}$ At the Y's Camp Pine Crest, spiritual goals were likewise refracted through a psychological lens. A 1951 report declared, "Our primary concern ... is for the all round growth and personality development of each individual, in ways consistent with our Christian ideals." 84

As in earlier decades, campers' parents and home life came in for criticism in post-war years. If post-war families put great stock in the value and comforts of home, and if educators continued to regard it as a key influence in a child's life, camp enthusiasts reflected the expert view that the home was not, by itself, enough. As was typical of this era, mother-blaming was common. In Mary Northway's writings, some middle- and upper-class mothers were accused of "protecting [the child] 
as a little god," while others, of "thrust[ing him] brutally at an early age to fend for himself." ${ }^{85}$ In Fresh Air Fund appeals, working-class mothers were blamed for creating homes of "constant bickering" 86 and for their tendency "to leave dust unmolested on the floors, to leave beds unmade, dishes unwashed, clothes unhung and children untended." ${ }^{87}$ Such criticisms suggested, as did modern psychology and the mental hygiene movement, that other socializing agents were needed, not just as a last resort for difficult children, but to keep all children on the path of normal child development. In effect, the home was reconceptualized as only one in a constellation of factors which promised to turn out the properly socialized child. As the province's Chief Director of Education claimed in 1947, "It is wholesome ... for boys and girls to get away for a time from their home, no matter how good that home may be." 88 Others agreed that extra-familial institutions had distinctive roles to play. "The family and the camp have different objectives," director Mary Hamilton stated in 1958. "The family is concerned mainly with the individual interests of the child, while the camp sees the child as a member of a group and seeks her adjustment to it." ${ }^{89}$ Clearly, as in the wider society, the mental hygiene point of view now permeated the articulation of camp goals, the planning of camp programming, and thinking about the camper one hoped to change.

\section{"Like Progressive Schools in the Outdoors"}

From the late 1920 s onward, camp life was influenced not only by psychological, but also educational expertise. As early as 1929, Camping and Character was proclaiming that efficient camp programming required "the most critical consideration of educational technique." 90 Ten years later, Camp Ahmek's "Talks to Counsellors" stated: "The whole life of the camp is the curriculum. The process of living, the interaction of persons within activities of many sorts ... constitute the educative process." ${ }^{91}$ By 1936 CGIT literature preached a similar message, that camping was "a necessary part of the modern girl's education." ${ }^{92}$ By the post-war period the influence of educational theory at camp was widespread and, accompanying it, a keen sense of the movement's progress. As a brochure from the private Camp Wabikon stated in 1952, "for a long time we thought of camp as a place to send youngsters to get them out of the city for the summer. This is still worthwhile, but camping today is recognized as a unique educational experience." ${ }^{93}$ Administrators of private, fresh-air, and agency camps agreed that something new was going on; that camping itself represented "one of the most significant educational innovations of the century." 94 Though its relationship to formal education was conceptualized as auxiliary or complementary, by the closing months of World War II it was proudly proclaimed that "the best summer camps are like progressive schools in the outdoors." 95

As much as camp administrators felt like they were embarking on a unique pedagogical journey, by the 1930s, ideals of progressive education were the much talkedabout fashion in educational circles throughout North America. In particular the ideas of John Dewey, American philosopher and educator, were taken up by numerous others and formed the basis for what became known as "progressive" education. 
Among the key aspects of Dewey's approach was the call to respect each child as an individual, with varying and specific needs. Indeed, Dewey castigated traditional education for its lack of innovation, its reliance on rote-learning, its narrow definition of the curriculum, and its coercive disciplinary practices. By contrast, his new approach promised "education for the whole child," that would unfold in an organic and child-centred way. In this respect, the "field trip" — an adventure out into the "real world" - might be more useful than the typical teacher-led lesson. Ultimately, Dewey envisioned that children educated in this manner would not only evince an open and creative attitude towards learning, but would grow into adults appreciative of the aims of a truly democratic society. ${ }^{96}$ Education defined in this way clearly fit well with the aims and perspective of the mental hygiene movement.

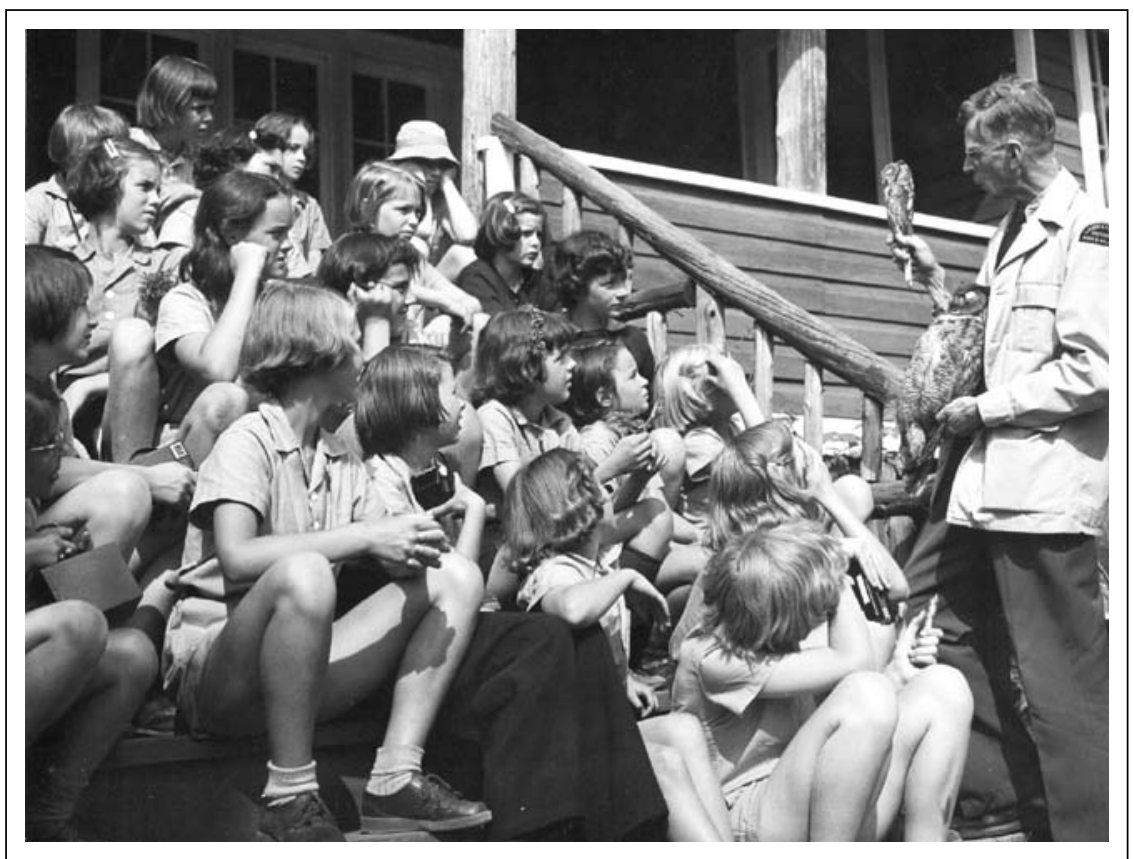

R.D. Usher at Camp Tanamakoon, 1951. Camp administrators were proud to claim that their education was more truly "hands on" than that provided by formal systems of education, a point which seems to be made here, as this park naturalist provides campers with a close-up view of bird life. Algonquin Park Museum Archives \#728 (Lands and Forests).

Camp administrators were influenced by these new trends and regarded their own work as part of the progressive movement in education. At many camps, for instance, much was made of the shift from regimented programming to a free and open system of activities, increasingly to be chosen by campers themselves. Camps self-consciously promoted this notion of their work and of how far it had come since the "old days" of camping. In 1939, after his conversion to a more child-centred programme, director Taylor Statten was already looking back on his early approach to camping as 
"militaristic." 97 This Whiggish view of the movement's progress was shared by others. By 1940, Mary Northway was claiming of camps in general that, "Informality has largely superseded highly scheduled programmes.... No longer does the director ... prepare a curriculum complete for every day of the season." ${ }^{98}$ This perspective seemed to hold sway equally at fresh air and agency camps. In 1947 Bolton administrators proudly declared, "There is nothing institutional about Bolton Camp. Every activity is planned for the utmost enjoyment of each individual child....Every child is treated as a guest and there is no regimenting. Each can do what he likes best." 99 Likewise, the YMCA boasted of the "free and easy informality" at Camp Pine Crest in $1942 . .^{100}$

Along with the new-found antipathy for regimentation, the adoption of a childcentred approach transformed attitudes towards competition and punishment at many camps. In the 1920 s, children had been encouraged to work at their camp skills by the awarding of all manner of prizes, badges, and trophies. Even girls, generally discouraged from competing and from developing an active physicality in schoolbased physical education programmes, were not entirely excluded from competition at camp, even if they were treated more carefully than boys. ${ }^{101}$ Female campers competed in end of season all-day "colour wars" at Camp Kawagama, for the "Worthy Woodsman" award at Tanamakoon and sometimes, at their own behest, to set the record for, in one case, the fastest canoe trip time. ${ }^{102}$ From the perspective of the progressive educator, however, competition was regarded as an artificial way of encouraging interest, and awards, as behaviourist crutches. Echoing the progressive educator's love of education for its practical application, camps now sought to have children "do things because they wanted to" and not simply to achieve recognition or "points." In the 1930s Ahmek consciously sought to "eliminat[e] competitions as far as possible." The practice of awarding prizes of many kinds was abandoned and even debates were considered "taboo" "because of the competitive element." 103 At Camp Tanamakoon, the administration looked back somewhat smugly on the years when the awarding of trophies was common: "The old cups at Tanamakoon are safely stored in cupboards as a memento of ancient days," 104 director Mary Hamilton stated in 1958. At the Y's Camp Pine Crest, administrators agreed this was the kind of learning that would "probably stick," since "boys found learning an enjoyable process, which they did because they wanted to; they did not have to learn." 105 Overall, camps were less concerned with skill acquisition than with socialization, now the camp's highest goal: "The experience of campers in social relationships is what influences or educates them," Camp Ahmek's 1939 handbook stated, "not the activities of swimming, canoeing, dramatics ... as such." ${ }^{106}$ Under the new system, corporal punishment — still freely resorted to in formal educational settings, but increasingly under fire from modern psychology — was officially frowned on and forms of positive reinforcement advocated in their place. As Taylor Statten optimistically suggested to counsellors in 1939, "I hope we shall be able to go through the entire season without using the word 'don't.", 107

The influence of new pedagogical theories was experienced not just in a negative sense (discouraging regimentation and competition), but also in a positive 
one-encouraging a hands-on and direct approach to learning. Camps took great pride in the fact that, as they saw it, children learned much more at camp than "within the four walls of any school," as YMCA promotional literature put it. ${ }^{108}$ Administrators at Ahmek relished the story of the school-teacher who instructed her students, "You'll have to stop picking those flowers now and come in for your botany lesson." 109 The weaknesses of formal education were, in fact, regularly noted. A reviewer of Camping and Character stated: "The primary purpose of the authors has been to set forth the camp as an educational agency, succeeding in fulfilling a function wherein the state school, weighed down by authority and tradition, is failing. Education today is a thing disassociated with life, a thing of air-tight compartments with no incentives and no motives, and sadly warped ideals." 110

In contrast, it was thought that learning at camp had a purpose, an application that made its acquisition attractive and meaningful. For instance, participation in much-anticipated canoe out-trips was dependent on one's ability to paddle and swim. According to the same thinking, camp lessons in geography and weather took place at an experiential and not intellectual level. "Maps are no longer things belonging to blackboards, but tools to help the camper arrive where he wants to go," Mary Northway insisted in 1940. "[C]louds are known as indicators of weather, and wind direction becomes an item to watch and consider." ${ }^{111}$ Even at fresh air camps where camping trips often involved no more than an overnight in the woods, it was proudly stated of boy campers in 1950: "Their campcraft is put to work immediately. They learn how to use knives and axes to build themselves bough beds on overnight campouts." 112 Likewise at the Y's Tapawingo for girls, a 1951 report claimed that, "[C]hildren learned campcraft by doing," and not via formal classes. ${ }^{113}$ In each case, as with the much-publicized "project approach" of the new educators, knowledge was not to be broken down into discrete subjects, but absorbed unconsciously as an integrated whole. Mary Northway was openly critical of those who resisted this approach, stating, "I have known camps where 25 parts of a sailboat have had to be learned before one can go sailing. Children are not very interested in learning names difficult to spell and to pronounce. They are interested in being in a dinghy on a windy day." 114

Progressive education at camp also meant the training of a new kind of "teacher" - the counsellor. Of all leaders, it was agreed that the counsellor was "the most vital single factor in the camp situation" and, as some put it, "the most important man in camp." 115 Except for a half-holiday per week, counsellors were expected to be on the job every moment of the day not only getting campers out of bed in the morning, monitoring their bodies and behaviours, and teaching them camp skills, but also acting as living, breathing examples of health, fitness, right values and attitudes. All told, counsellors were expected to show the understanding of a psychologist, the loving guidance of a parent, but also, as one source put it, "something of the detachment of a doctor." 116

If no one seriously regarded camp as a replacement for formal schooling, this did not prevent its promoters from designing grand visions of its scope and potential. As early as 1937, The Toronto Star was sharing the ideas of an American camping authority who called for "large public camps near every city in Canada and United States." 
As part of the public system of education, he predicted that government-owned summer camps would be "the next big step forward in education." ${ }^{117}$ In the final analysis, camp administrators saw themselves as the most truly progressive educators, those who had grasped the genius of "the natural." This "natural-ness" described both its setting (in wilderness and rural contexts) and its structure (child-centred and holistic). By contrast, traditional education was deemed doubly artificial: set in the constructed spaces of urban society and organized in a constructed and artificial manner. As Camping and Character stated, "The paramount educational asset of the summer camp ... lies in the naturalness and simplicity of life in the woods in contrast with the complexity and artificiality of civilized city life." ${ }^{118}$ Even in their "modern-ness," then, camp enthusiasts revealed their anti-modern tendencies.

\section{Assessing the Impact of Progressive Education at Camp}

One of the early conclusions of Canadian historians of progressive education is that, quite simply, the movement failed to have significant impact. From this view, problems of understaffed institutions, teachers untrained in the application of progressive pedagogy and the desire to turn out well-behaved citizens and malleable workers meant that formal education in Canada continued to function much as it always had until at least the 1960s. In Neil Sutherland's view, the 1920s to the 1950s saw, not a progressive educational breakthrough, but rather, "the triumph of formalism." ${ }^{119}$ More recently, Paul Axelrod has concluded of the 1950s that results were mixed; that post-war educators were "imperfect problem solvers, neither as villainous nor as saintly as their conflicting popular images implied." ${ }^{120} \mathrm{My}$ assessment of the camp experiment with progressive education leads to similar conclusions. Camp programmes revealed a complex mix of success and failure in the experiment with progressive education.

Admittedly, camps, like schools, did not always live up to educational ideals. For one, the freedom of programming was sometimes exaggerated. Fresh air camps for the poor, with their often large numbers and low staff/camper ratios, were particularly susceptible to on-going regimentation. While fresh air literature painted a picture of the "free and easy" life of camp, this was clearly an exaggeration. ${ }^{121}$ In fact, along with its admiration for freedom, promotional literature revealed an abiding respect for efficiency and order. "At the fresh air camps there is a definite routine," The Toronto Star noted appreciatively as late as 1949. "Certain activities take place at a certain time. Meals are served at a definite hour. There is a rest period every day which every child ... must observe." ${ }^{122}$ At these camps with large camper populations, a degree of regimentation was no doubt a necessity. For instance, teaching children camping and sporting activities "in shifts of one hundred at a time," as at one fresh air camp on Georgian Bay, clearly did not allow for either individual attention or a free and easy approach. ${ }^{123}$

Even smaller, private camps sometimes displayed a similar attachment to regimentation. In 1946 the OCA had only praise for the "apple pie order" at Camp Tanamakoon, where even staff meetings were infused with a determined efficiency. 


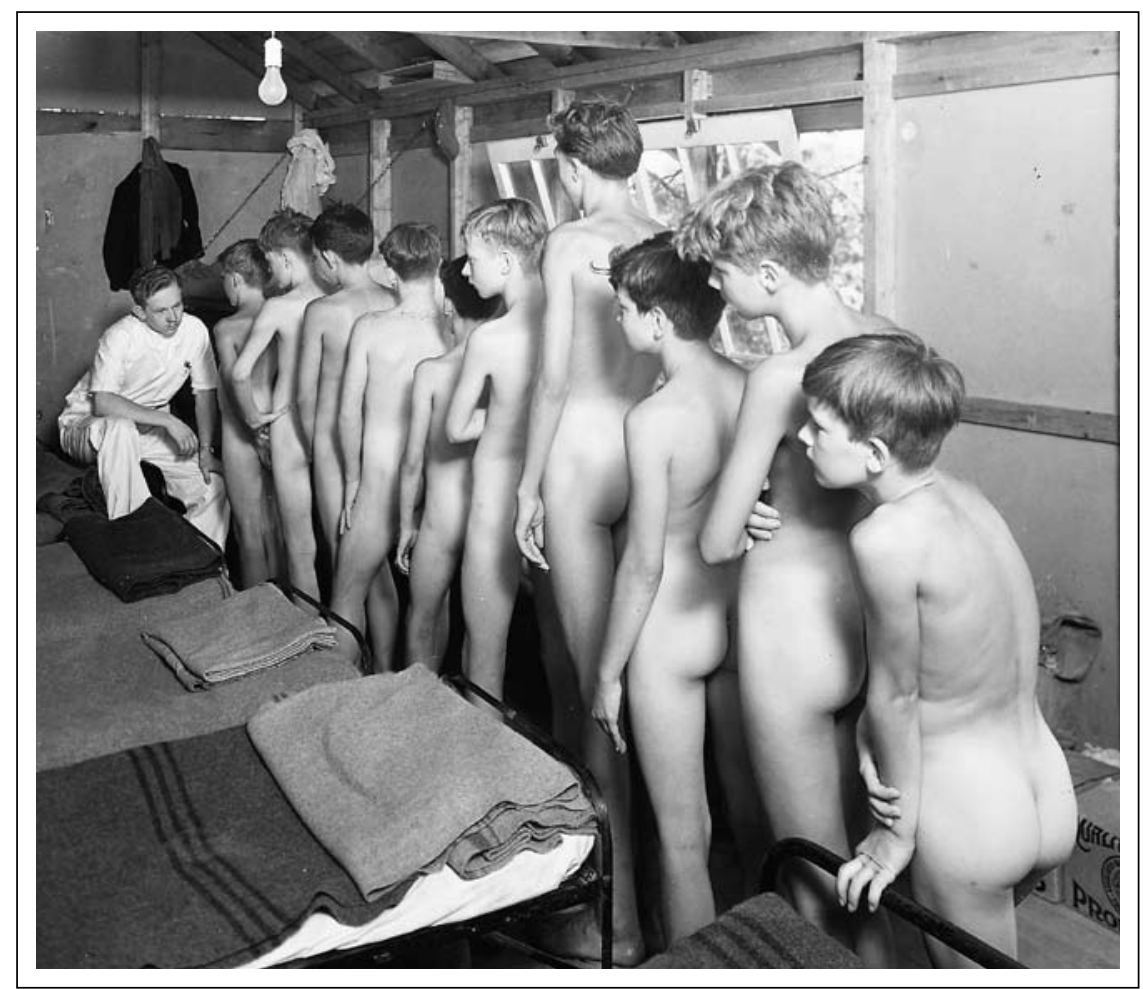

Medical Inspection, Bolton Camp, 1936. As this photo suggests, it was not always possible to achieve the childcentred tone and individualistic approach favoured by progressive pedagogy, especially at fresh air camps which accommodated large numbers of campers each summer. Courtesy Family Service Association of Toronto.

"Avoid lounging, starting a personal conversation, or making irrelevant remarks," was the camp director's advice. "State your problems and outline what you have to say, clearly and without loss of time." ${ }^{124} \mathrm{~A}$ similar perspective guided Tanamakoon's organization of camper activities. "Tripping was not a topsy-turvy outing," it was proudly stated of this same camp; rather, "the more efficient the trip, the happier it was." 125 The urge to slip off into the wilderness, to experience the simplicity and grandeur of nature, co-existed somewhat tensely with the on-going desire for respectability, as advice at Ahmek suggested. "Canoe trip camping means constant warfare against untidy equipment and personal uncleanliness," trippers were informed in 1948. "Don't carry a mirror, but ask someone how you look about the third day out." ${ }^{126}$ Departing from camp clearly did not mean departure from decorum or, for counsellors, release from detailed record-keeping. Far from it, counsellors were instructed to keep careful reports of all activities, weather, accidents, and behaviour, as well as, generally, to "discourage the hobo attitude." 127

Youthful counsellors, as already noted, were not always the wise and willing teachers of progressive ideal. At times, some acted more like disgruntled workers than as dedicated instructors or psychologists in training. A 1931 study of Ahmek noted 


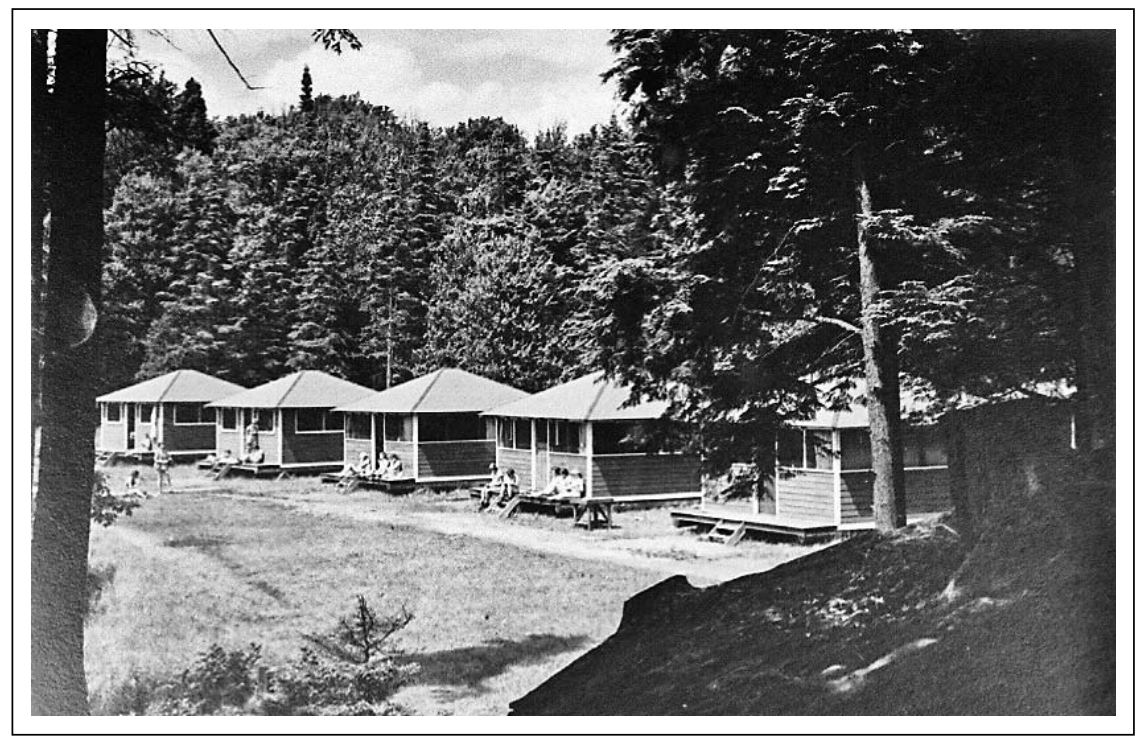

Cabins at Camp Tanamakoon. In theory, progressive educationalists valued freedom and rejected regimented approaches, but they could not always dispense with regimentation at camp. As the placement of these cabins suggests, even the physical landscape at camp was a careful balance of natural setting and orderly planning. Algonquin Park Museum Archives \#3137 (George May).

that counsellors were not always enthusiastic, for instance, about the "great amount of "clerical work" or record-keeping demanded by the camp." ${ }^{128}$ In 1938 a final report from the camp indicated "a certain feeling of tension among staff members," that some felt that "much fun ha[d] departed" from camp life and were ready to "pack [their] trunk[s]." ${ }^{129}$ At the Y's Camp Pine Crest, reports likewise complained of counsellors who were "not at all qualified," who lacked "personalized interest" and who weren't overly interested in the details of "campers' routine." 130

From the perspective of campers, relationships with counsellors were sometimes more distant than warm. In part, this distance was built into the structure of camp, where counsellors did not always share cabins with campers, an arrangement said to foster independence and co-operation among campers. ${ }^{131}$ "When I was in intermediate camp," Shirley Ford remembered of 1930s Glen Bernard, "our counsellor came into the cabin the first day and said, 'Hi, I'm so-and-so,' and we didn't see her again for weeks." ${ }^{132}$ Bolton fresh air camper, Mary Murphy, also confided that she had few memories of her counsellor, in her view, "because they weren't that personal with you." 133 In their defence, one might add that counsellors were often warned to keep their distance from campers, due to fears of encouraging "crushes" and, in the worstcase scenario, homosexuality. Here, it was thought, camp had some developmental hazards as well as benefits. ${ }^{134}$

In some cases, children themselves sometimes could find camp a less than agreeable experience, whatever the belief that learning was to be an organic and enjoyable process. Indeed, for some, psychological health was more threatened than enhanced by 
the camping experience. No matter how good the camp, separation from parents and home - for private campers, sometimes as long as two months - could be traumatic. Ahmek reported that each year at its camp saw two or three cases of "hysterical homesickness," campers like fourteen-year-old "Tom" who rarely slept through the night. "I would trade you places any day," he was said to have written home to his brother. "I was sick the other night and it was heckish.... When you see the Pirate Ship in the camp book it looks big but it is small. So is the theatre. ... I am in the Intermediate section and it's not much good....I hope Mom and Dad come home ... so I will be able to go home. I will tell you straight that I will not come back here any more." 135

Even those campers who generally took to camp life, sometimes found homesickness a persistent problem and one of the psychological challenges of camp. RuthEllen Soles cried herself to sleep the first night of every camp season. "I did until I was eighteen," this 1950s Kawagama camper explained. "It became a ritual." ${ }^{136}$ According to a 1957 study of homesickness at fifteen camps, this was one of the most common manifestations, as were sleep and digestion problems. In many of these cases, homesickness was accepted as a natural reaction, even a healthy part of growing up. A smaller number, however, became cause for more intense behaviour problems, suggesting that, as historian Leslie Paris has found at American camps, homesickness might have been an expression of campers' "semi-official and unofficial dissent." 137

Apart from painful separation from family and friends, certain campers experienced the peer group in a mainly negative fashion. The bed-wetter, the physically uncoordinated, or the fearful child could all find camp to be a miserable experience. Peer group adjustment was clearly not always smooth. At Glen Bernard Camp it was noted in the 1930s that bullies could be "cruel and cutting," and that, generally, "In a community such as this, one or two people actually develop the role of the scapegoats of the group." 138 While scapegoating also occurred at school, at camp there was not even the chance of daily reprieve.

The freedom so valued by the progressive educator could lead to other uninvited behaviours at camp. Pranks and practical jokes were common at many camps and, as Paris argues, were largely tolerated, if not sanctioned, by camp managements. Other sorts of camper activities and responses were considered more problematic. Camp Ahmek literature referred disapprovingly to the misuse of equipment, night-time "tent feeds," "dangerous risk-taking," and to lack of cleanliness and punctuality as general problems. A 1947 report on staff training referred to some campers as "complacent," "aggressive," and "unco-operative." ${ }^{139}$ Psychologist Mary Northway was open in criticizing the lack of discipline at some camps: "[I]t has become the tradition to have fun by breaking the rules, by rowdyism and lack of discipline," she noted disapprovingly. "At some camps bedtime is set for 9:30, and at eleven, twelve and even two o'clock, campers are found running about disturbing others, raiding tents, waking the maintenance staff — and this is considered having fun." ${ }^{140}$ Whatever the rhetoric of progressive pedagogy, clearly, a certain level of regimentation was still seen as indispensable.

For their part, staff did not always choose the most progressive approaches in dealing with misbehaving children. Interviews revealed at least two cases of counsellors hitting children, and one camper being shut up alone in her cabin for "about a day 
and a half." ${ }^{141}$ While Taylor Statten assured the public in 1939 that "the attitude of the camp is that punishment is unnecessary," ${ }^{142}$ clearly, this did not mean that staff at every camp always took a genial, permissive approach.

If camps were not the utopian worlds and controlled laboratories their administrators envisioned, neither did they fail entirely at their educational mission. As with other social institutions, a gap between goals and reality was always apparent, but in terms of the camp setting this did not necessarily entail the "triumph of formalism." In part, this can be read from children's own reactions. For every child who regretted the experience, there were many more for whom camp was a special and long-remembered treat, one they would no doubt look back on in adulthood as "educational." The Y's Camp Pine Crest was proud to report all the positive experiences at camp in the summer of 1940. "Fifty-two boys extended their Camp periods. Two boys visited the camp and liked it so well they stayed the rest of the summer. Several little boys cried when they had to go home. An eight-year-old wrote back to the director after he left camp: 'I like Camp very much. I would like to stay next year." 143 True enough, many campers showed an excitement, delight, and, sometimes, devotion rarely expressed in connection with institutions of formal education. "Hysterical homesickness" and major behavioural problems appear to have been a minority problem, with many children preferring camp life to school. According to Geraldine Sherman, post-war Kawagama camper, "The most eager campers were those who most hated school." 144

What we know of camp programming and organization further suggests that the summer camp was at least partly successful in its experiment with progressive education. Camps were often more regimented than their literature admitted, but, for many campers, they also offered the most freeing and relaxed atmosphere of any childhood experience. For such campers, it is not the bells and the bugles which are now remembered, but rather the liberty to experiment with new activities and the general feeling of independence this engendered. Some experienced this particularly in terms of the distance from parental control; others, like Wapomeo camper, Joan Moses, found simply that the pace of camp life was to their liking. "Being a senior girl — from 14 on," she recalled, "we had our own little island across the way from the main girls island. ... The counsellors had their own separate cabins and we had the cabin to ourselves. There were no inspections and if you didn't make your bed the whole summer, that was your problem - and some didn't!" 145 In Moses' experience, camp was very much a world unto itself, where the peer culture of youth dictated the pace as much as the camp administration.

This type of behaviour was not permitted at every camp, nor for all ages of campers. For some campers it was time spent away from camp, canoe-tripping, that offered the widest scope for autonomy. Out on canoe trips, one was removed not only from parental control, but from that of most of the camp administration. With only several counsellors - perhaps not much older than themselves - and two or three guides, campers paddled their way through adventure and adversity, with a sense of freedom and independence likely both physical and psychological. Merle Storey looked back on her experience with a bittersweet nostalgia: 
I remember struggling across the portages with the unaccustomed weight of a pack on my back, welcoming the sight of the end of the portage where a canoe was waiting to be loaded, paddling down the silent lakes with only the sound of our own voices echoing across the water and gathering around the campfire at night with the dark forest beyond. It was an unforgettable experience..... ${ }^{146}$

While demanding its own kind of discipline, in a sense, tripping eliminated the need for formal regulations, the ultimate goal of the progressive educator. At Keewaydin, where tripping was the very centrepiece of camp life and in-camp programming virtually non-existent, there was apparently little need for a set of official prohibitions: "Rules didn't exist," claimed 1940s camper, Douglas Creelman. "Thinking about it afterwards, [I realized] we were probably too tired to get into trouble." ${ }^{147}$ If administrations were sometimes preoccupied with orderliness and efficiency on trips, this is not what many campers seem to remember.

Even aside from canoe-tripping — not a part of every camp's programming — other aspects of activity planning helped to imbue camps with a more child-centred tone than most schools. Indeed, in contrast to the school, with its concern for wellroundedness and facility with every subject, camp programming frequently allowed children to focus on those activities of most interest to them. This scenario was less likely to be found at larger camps, where moving large numbers of children from activity to activity did not allow for the same individual freedoms. Even there, however, the structuring of programming - involving hands-on "doing" and active physicality, rather than abstract thinking, as well as the general novelty of setting and activities - appears to have made a trip to camp an enjoyable and sought-after privilege for many. More than this, camp provided its own kind of education - about the natural world, about the regions in which children camped and travelled, about physical ability and stamina, and about getting along with others. School educators might well have been envious of this relative success.

\section{Conclusion}

As the authors of Camping and Character saw it, the application of psychology to the realm of outdoor education heralded the emergence of "the modern summer camp." In this view, to be modern was to grasp the importance of the camp as the tool of social science and education, to understand the parameters and importance of child psychology, and to enthusiastically apply the insights of progressive pedagogy. This striving to "be modern" might seem at odds with the camp's natural ethos and simple life rhetoric. In fact, this two-sidedness, the pull of the modern and the anti-modern were both essential aspects of the camp phenomenon. In the eyes of camp promoters and administrators, successful modern living entailed regular trips back to the natural (read: pre-modern) world. When individuals like Mary Northway, accomplished academic and successful camp director, claimed later in life that, "There was a time when I felt that I was living kind of a schizophrenic life: one side getting a Ph.D. in psychology, the other, running a camp, and never the two should meet," 148 she was 
perhaps alluding to contrasts between the male-dominated world of scholarship and the all-female setting of camp. Certainly, on a broader level, the two did meet, academic psychology deeply impacting the camping movement, and the camp, turning out children - in its own eyes at least - of sounder psychological health. As administrators agreed, camp was "a new type of education ... made necessary by modern conditions." ${ }^{149}$ Ultimately, whatever the anti-modern aspects that inspired its birth, when it came to its vision of childhood and education, the summer camp had its face not backwards towards the past, but toward a future where children would be increasingly analysed, understood and shaped by the tenets of psychological and educational expertise.

\section{Acknowledgements:}

The author wishes to thank David Burley as well as the editors and anonymous reviewers at HSE for many helpful comments on an earlier draft of this paper.

\section{Notes}

1 Ontario Camp Leadership Centre files in possession of Dorothy Walter, Toronto, Ontario, Dr. J.G. Althouse, Transcript of CKEY Broadcast, 25 April 1947, 1.

2 Anthony Giddens, Modernity and Self-Identity: Self and Society in the Late Modern Age (Stanford: Stanford University Press, 1991), 144-80.

3 Giddens, Modernity and Self-Identity, 18.

4 In Rooke and Schnell's view, Victorian childhood was defined by four essential factors: segregation from, and also protection by, adult society, as well as social and economic dependence. Patricia T. Rooke and R. L. Schnell, "Childhood as Ideology," British Journal of Educational Studies 27 (February 1979): 7-28. On child labour, see Lorna Hurl, "Restricting Child Factory Labour in Late Nineteenth-Century Ontario," Labour / Le Travail (Spring 1988): 87-121; Dominique Jean, "Le Recul de travail des enfant au Quebec entre 1940 et 1960: Une Explication des Conflits entre les Familles Pauvres et L'Etat Profidence," Labour / Le Travail 24 (Fall 1989): 91-129; John Bullen, "Hidden Workers: Child Labour and the Family Economy in Late Nineteenth-Century Urban Ontario," Labour / Le Travail 18, (Fall 1986): 163-87. In the American context, see Viviana A. Zelizer, Pricing the priceless child: the changing social value of children (New Jersey: Princeton University Press, 1994).

5 On psychology and child development theories, see Steven Schlossman, "Philanthropy and the Gospel of Child Development," History of Education Quarterly 21, no. 3 (1981): 275-99.

6 As Sol Cohen explains, these bodies were constituted by "reform-minded academicians, social workers, physicians and psychiatrists" Sol Cohen, "The Mental Hygiene Movement, The Development of Personality and the School: The Medicalization of American Education," History of Education Quarterly, 23 (Summer 1983): 136-7.

7 Mona Gleason, Normalizing the Ideal: Psychology, Schooling, and the Family in Postwar Canada (Toronto: University of Toronto Press, 1999), 19.

8 A department of psychology also emerged at McGill University in the 1920s. Mona Gleason provides one of the most informative accounts of the rise of academic psychology in this country. Gleason, Normalizing the Ideal, 19-36. On the mental hygiene movement, see Schlossman, "Philanthropy and the Gospel of Child Development”; Cohen, “The Mental Hygiene Movement”; Theresa R. Richardson, 
The Century of the Child: The Mental Hygiene Movement and Social Policy in the United States and Canada (Albany: State University of New York Press, 1989), 112-27; Hans Pols, "Between the Laboratory and Life: Child Development Research in Toronto, 1919-1956," History of Psychology 5, no. 2 (2002): 135-62; Brian J. Low, “The New Generation: Mental Hygiene and the Portrayals of Children by the National Film Board of Canada, 1946-1967," History of Education Quarterly 43, no. 4 (2003): 540-70; Brian J. Low, "The Hand that Rocked the Cradle: A Critical Analysis of Rockefeller Philanthropic Funding, 1920-1960" Historical Studies in Education 16, no. 1 (2004): 33-62; Neil Sutherland, Children in English-Canadian Society, 1880-1920: Framing the Twentieth-Century Consensus (Toronto: University of Toronto Press, 1976, reissued by Wilfrid Laurier University Press, 2000), chapter 1. On forced sterilization of the "feebleminded," see Angus McLaren, "The Creation of a Haven for "Human Thoroughbreds": The Sterilization of the Feeble-Minded and the Mentally Ill in British Columbia," Canadian Historical Review 67, no. 2 (1986): 127-50 and also his monograph, Our Own Master Race: Eugenics in Canada, 1885-1945 (Toronto: McClelland and Stewart, 1990).

9 Miller, "Psychology and the Child," 57-80; John Cleverley and D. C. Phillips, Visions of Childhood: Influential Models from Locke to Spock (New York: Teachers College Press, 1986), 114-24. On the Canadian setting, see Veronica Strong-Boag, "Intruders in the Nursery: Childcare Professionals Reshape the Years One to Five, 1920-1940," in Childhood and Family in Canadian History, ed. Joy Parr (Toronto: McClelland and Stewart, 1982), 160-78; Nora Lewis, "Creating the Little Machine: Child-rearing in British Columbia, 1919-1939," BC Studies 56 (Winter 1982-83): 44-60; Katherine Arnup, "Raising the Dionne Quintuplets: Lessons For Modern Mothers," in the special issue of Journal of Canadian Studies 29, no. 4 (Winter, 1994-95): 65-84 and other articles; Katherine Arnup, Education for Motherhood: Advice for Mothers in Twentieth-Century Canada (Toronto: University of Toronto Press, 1994), 84-116; Cynthia Comacchio, Nations are Built of Babies: Saving Ontario's Mothers and Children (Montreal/Kingston: McGill-Queen's University Press, 1993).

10 Jocelyn Motyer Raymond, The Nursery World of Dr. Blatz (Toronto: University of Toronto Press, 1991), 42. On John B. Watson and behaviourism, see Peter J. Miller, "Psychology and the Child: Homer Lane and J.B. Watson," in Studies in Childhood History: A Canadian Perspective, eds. Patricia T. Rooke, R.L. Schnell, (Calgary: Detselig Enterprises Ltd., 1982), 73; Ann Hulbert, Raising America: Experts, Parents and a Century of Advice About Children (New York: Alfred A. Knopf, 2003).

11 For biographical information on Blatz, see, again, note 16. For Blatz's camping involvement: Hedley S. Dimock and Charles E. Hendry, Camping and Character: A Camp Experiment in Character Education, (New York: Association Press, 1929), 159; Trent University Archives [hereafter TUA], OCA Papers, 78-006/1/1, 'Second Annual Report of the Committee on Education and Research of the Ontario Section of the American Camping Association," April 13, 1942.

12 Blatz also served as consultant to the Toronto Juvenile Court and on-site psychologist at several Toronto schools. See Raymond, Nursery World of Dr. Blatz; Richardson, Century of the Child, 112-27; Gleason, Normalizing the Ideal, 27-51; Strong-Boag, "Intruders in the Nursery." Mona Gleason points out the theoretical underpinnings of Blatzian psychology are still a matter of debate. Gleason, Normalizing the Ideal, 43-44.

13 Existing histories of Canadian summer camps are sparse, although a smattering of articles has appeared on the subject. See the collection of articles in Bruce W. Hodgins and Bernadine Dodge, eds., Using Wilderness: Essays on the Evolution of Youth Camping in Ontario (Peterborough: Frost Centre for Canadian Heritage and Development Studies, 1992). See also Susan L. Forbes, "Nothing But a Rag Between You and the Sky': Northway Lodge Girls' Camp and the Wilderness Experience," paper given to the 
Canadian Historical Association Conference, Edmonton, May 24-29, 2000; Anna H. Lathrop, "Strap an Axe to Your Belt': Camp Counselor Training and the Socialization of Women at the Margaret Eaton School (1925-1941)," Sport History Review 32, no. 2 (2001): 110-25; and Sharon Wall, "Totem Poles, Teepees and Token Traditions: 'Playing Indian' at Ontario Summer Camps, 1920-1955," Canadian Historical Review 86, no. 3 (September 2005): 513-44. On the history of summer camps in the American setting, see Leslie Paris, "Children's Nature: Summer Camps in New York State, 1919-1941" (Unpublished Doctor of Philosophy dissertation, University of Michigan, 2000); Leslie Paris, "The Adventures of Peanut and Bo: Summer Camps and Early Twentieth Century American Girlhood," Journal of Women's History 12 (Winter 2001): 47-78; Susan A. Miller, "Girls in Nature/ The Nature of Girls: Transforming Female Adolescence at Summer Camp, 1900-1939" (Unpublished Doctor of Philosophy dissertation, University of Pennsylvania, 2001); Michael B. Smith, "'And They Say We'll Have Some Fun When It Stops Raining: A History of Summer Camp in the United States" (Unpublished Doctor of Philosophy dissertation, Indiana University, 2002); Michael Smith, "The Ego Ideal of the Good Camper and the Nature of Summer Camp," Environmental History (Jan. 2006), http://www.historycooperative.org/journals/ eh/11.1/smith.html (accessed August 18, 2007); Nancy Mykoff, "A Jewish Season: Ethnic American Culture at Children's Summer Camp, 1918-1941" (Unpublished Doctor of Philosophy dissertation, New York University, 2002); and Abigail Van Slyck, A Manufactured Wilderness: Summer Camps and the Shaping of American Youth, 1890-1960 (Minneapolis: University of Minnesota Press, 2006).

14 "Urbanization," The Canadian Encyclopedia (Edmonton: Hurtig Press, 1988), 2235.

15 On changing views of nature, see Roderick Nash, Wilderness and the American Mind (New Haven: Yale University Press, 1973); Elizabeth McKinsey, Niagara Falls: Icon of the American Sublime (Cambridge: Cambridge University Press, 1985); William Cronon, ed., Uncommon Ground: Toward Reinventing Nature (New York: W.W. Norton and Company, 1995); Max Oelschlaeger, The Idea of Wilderness: From Prehistory to the Age of Ecology (New Haven: Yale University Press, 1991); and Peter Schmitt, Back to Nature: The Arcadian Myth in Urban America (Baltimore: John Hopkins University Press, 1990). On nature-based recreation and its therapeutic effects in the Canadian context, see Roy I. Wolfe, "The Summer Resorts of Ontario In the Nineteenth Century," Ontario History 54, no. 3 (1962): 149-61; George Altmeyer, "Three Ideas of Nature in Canada, 1893-1914," Journal of Canadian Studies 11, no. 3 (1976): 21-36; Douglas Cole, "Artists, Patrons and Public: An Enquiry into the Success of the Group of Seven," Journal of Canadian Studies 13, no. 2 (Summer 1978): 69-78; G. Wall and J. Marsh, eds., Recreational Land Use: Perspectives on its Evolution in Canada (Ottawa: Carleton University Press, 1982); Bruce W. Hodgins and Margaret Hobbs, eds., Nastawgan: The Canadian North by Canoe and Snowshoe (Weston: Betelgeuse Books, 1985); Bruce W. Hodgins and Jamie Benidickson, The Temagami Experience: Recreation, Resources, and Aboriginal Rights in the Northern Ontario Wilderness (Toronto: University of Toronto Press, 1989); Patricia Jasen, Wild Things: Nature, Culture, and Tourism in Ontario, 1790-1914 (Toronto: University of Toronto Press, 1995); Jamie Benidickson, Idleness, Water, and a Canoe: Reflections on Paddling for Pleasure (Toronto: University of Toronto Press, 1997); Karen Dubinsky, The Second Greatest Disappointment: Honeymooning and Tourism at Niagara Falls (Toronto: Between the Lines Press, 1999); and Tina Loo, "Of Moose and Men: Hunting for Masculinities In British Columbia, 1880-1939," Western Historical Quarterly 32, no. 3 (2001): 296-319. On the creation of provincial parks during this same period, see K. Morrison, "The Evolution of the Ontario Provincial Park System," in Recreational Land Use, eds. Wall and Marsh, (Ottawa: Carleton University Press, 1982), 102-119; Gerald Killan, Protected Places: A History of Ontario's Provincial Parks System (Toronto: Dundurn, 1993). 
16 TUA, Ronald H. Perry Fonds, 82-016/2/8, "The Summer Camp: Recreation or Education," Canoe Lake Camp Echoes 4, no. 2 (April 1931), 13; "Come On! Kick in and Smile! Give Kids the Break You Got," Toronto Daily Star [hereafter TDS], August 28, 1930, 25.

17 TDS, June 24, 1920, 5; "Reminiscent Army Man Defines Joys of Childhood," TDS, July 2, 1943, 18 .

18 Abbie Graham, quoted in Hedley S. Dimock and Taylor Statten, Talks to Counselors, (New York: Association Press, 1939), 18.

19 Smith, "The Ego Ideal of the Good Camper."

20 TUA, OCA papers, 72-007/2/9, Irwin Haladner to staff members, "Letter \#1," May 1952. See also TUA, OCA Papers, 78-006/25/40, Charlie F. Plewman, "The Days Leading up to the Formation of the Ontario Camping Association" part of poster “Today: Tomorrow's Yesterday," c. 1967.

21 The C.S.E.T. programme was used by groups of 'Trail Rangers' (boys, twelve to fourteen years of age) and Tuxis boys (sixteen to seventeen years of age) and was designed to develop boys' intellectual, spiritual, physical and social capacities. C.A.M. Edwards, Taylor Statten (Toronto: The Ryerson Press, 1960); M. Lucille Marr, 'Church Teen Clubs, Feminized Organizations?: Tuxis Boys, Trail Rangers, and Canadian Girls in Training, 1919-1939,' Historical Studies in Education, 3, no. 2 (1991): 249-67.

22 On Mary Hamilton and the History of Camp Tanamakoon, see Mary G. Hamilton, The Call of Algonquin: Biography of a Summer Camp (Toronto: The Ryerson Press, 1958), 16. Lathrop, “'Strap an Axe to Your Belt'...”; John Byl "Mary G. Hamilton: Committed, Dedicated Pioneer Made A Difference," Canadian Association for the Advancement of Women and Sport and Physical Activity http://www.caaws.ca/e/ milestones/women_history/mary_hamilton.cfm (accessed August 4, 2007).

23 For biographical information on Mary Northway see TUA, Northway Family Fonds, 90-016/1/1, 'Fonds Level Description - Northway Family'; Curriculum vitae: Mary Northway, 1979. Northway is also mentioned by Raymond as a significant part of Blatz's work at the Institute and, indeed, as integral to the publication of Blatz's final study, Human Security. See Raymond, Nursery World, 144, 210-16, 220. Northway's dissertation was not only published but also translated into six other languages.

24 For just a few other examples, A.L. Cochrane and A.S. Clarke - founders of the first boys' camps in Temagami in 1903 - both held positions at private boys' schools, Cochrane at Toronto's Upper Canada College (UCC), and Clarke, at the Gunnery School, a Connecticut preparatory school. Mary S. Edgar, who founded Glen Bernard Camp near her home town of Sundridge in 1922, was involved in the YWCA, the CGIT and the Girl Guides. Because of her educational contributions to the world of camping, Edgar was named honorary trustee at Havergal girls' college, where she attended as a student in former years. For more on the life of Cochrane, see Upper Canada College Archives [hereafter, UCCA], Ann Hall, 'Arthur Lewis Cochrane: A Biographical Sketch,' unpublished paper, Queen's University, Kingston (1964): 36-37. For biographical information on A.S. Clarke and the history of the Keewaydin Camp, see Brian Back, The Keewaydin Way: A Portrait, 1893-1983 (Temagami: Keewaydin Camp Ltd., 1983). For biographical information on Edgar, see TUA, Northway Family Fonds - Additions, 90-016/1/34, Mary Northway, 'Mary S. Edgar, 1889-1973,' Canadian Camping Magazine, (Summer 1973); TUA, OCA Sound/Tape collection, 83-002/5/8, Barbara Gilchrist, interview by Jack Pierce, November 6, 1986.

25 Cohen, "Mental Hygiene Movement," 129.

26 "Have Alley as Playground, No Trees or Grass in Sight," TDS, July 5, 1924, 1.

27 Dimock and Hendry, Camping and Character, 145.

28 Ibid., 146. 
29 Mary L. Northway, Appraisal of the Social Development of Children at a Summer Camp (Toronto: University of Toronto Press, 1940), 12.

30 Dimock and Hendry, Camping and Character, 145.

31 Family Services Association of Toronto, Archival Collection, [hereafter, FSATA] "The Gateway to Health and Happiness: Bolton Camp Speaks Again, 1933," 15.

32 Dimock and Statten, Talks to Counselors, 19. For Blatz's notion of security see Raymond, Nursery World, 145-6.

33 Statten, Talks to Counsellors, 20; TUA, Ronald H. Perry Papers, 82-016/2/8, Dimock, "Camping and Character Growth," 12.

34 Dimock and Statten, Talks to Counselors, 20; "You're Tanned and Peppy, What About Poor Kiddies," TDS, July 21, 1948, 7; "Fresh Air Fund Needs \$417 Daily to Help 5,000 Children Left," TDS, August 31, 1950, 8; "Fund Helps Kiddies Escape Mental, Physical Collapse," TDS, July 7, 1947, 4. In 1937, the Project on Shy Children was initiated by University of Toronto psychologists. See Pols, "Between the Laboratory and Life," 148-50. On shyness as presented in postwar NFB films, see Low, "The New Generation," On the school's new approach to shy students, see Cohen, "The Mental Hygiene Movement," 131.

35 TUA, Northway Family Fonds - Additions, copy of Mary Northway, "Socialization," The Camping Magazine 11, no. 8 (1939): 4.

36 In 1958 Mary Hamilton reiterated Northway's sentiments, stating, "The camp is a child's world and it is very important that the child should feel at home with her own age group. The fact that she gets along at home, does not necessarily mean she can get along with her own contemporaries." Mary G. Hamilton, The Call of Algonquin: Biography of a Summer Camp (Toronto: The Ryerson Press, 1958), 101. On age consciousness, see Howard Chudacoff, How Old are You?: Age Consciousness in American Culture (Princeton: Princeton University Press, 1989).

37 FSATA, "The Story of Bolton Camp," in booklet "After Twenty Years: A Short History of the Neighbourhood Workers Association," 1938, 49.

38 FSATA, "Some Advances in Camp Programme, Bolton Camp Report, 1939." The YMCA's Camp Pine Crest also divided campers into four different sections according to age. TUA, Camp Pine Crest Fonds, 78-009/2/4, Camp Pine Crest, Brochure, 1945; TUA, Camp Pine Crest Fonds, 78-009/2/4, Camp Pine Crest, Brochure, 1946. Ahmek also made provision for "Inkies" and "Chippies" - the youngest campers, "seniors" and others in between. TUA, Adele and Harry Ebbs Papers, 80-014/1/8, "The Taylor Statten Camps," Brochure, c. 1950s; Joan Moses, interview by author, July 26, 2000.

39 On staff - camper ratios see TUA, OCA "1949 Directory of Member Camps"; TUA, OCA Papers, 82-009/2/2, "Northway Lodge: A Pioneer Camp for Girls," Brochure, 1941.

40 Statten, Talks to Counsellors, 11; TUA, Ronald H. Perry Papers, 82-016/2/8, Dimock, "Camping and Character Growth," 10.

41 TUA, OCA Papers, 78-004/2/31, Bert Danson, transcript of interview by J. Budge, February 15, 1973; TUA, OCA Sound/Tape Collection, 83-002/2/5, Mary Northway, interview by Cathy Stuart and Warren Anderson, January 21, 1975; TUA, Northway Family Fonds - Additions, 90-016/1/34, Mary Northway, "Recollection of Glen Bernard Camp," May 16, 1982; Shirley Ford, interview by author, June 20, 2000.

42 Mary Northway, "Socialization," 3.

43 On Palter's role at Camp Kawagama, see Geraldine Sherman, 'The Girls of Summer,' Toronto Life (September 2001): 100. Adult camp alumni from Kawagama have claimed that whenever one of her campers attained a degree of fame or notoriety - of good or bad variety - Palter returned to her original box of index cards, "well into old age," to verify the accuracy of her original impressions.

44 Everett Rogers lists five categories of response to the presentation of new ideas: the innovators, the early adopters, the early majority, the late majority and the laggards. 
Everett M. Rogers, Communication of Innovations: A Cross-Cultural Approach (New York, 1971), referenced in Cohen, "The Mental Hygiene Movement," 138.

Dimock and Hendry, Camping and Character, 256-7, 277.

46 According to Cohen, interwar parent education programmes, another offshoot of the mental hygiene movement, sought to change parents' 'pre-scientific' views and educate them as to the importance of personality development. Involving parents in studies and questionnaires was one way of drawing them in to the mental hygiene perspective. Cohen, "Mental Hygiene Movement," 129.

47 Dimock and Statten, Talks to Counselors, 86-7.

48 TUA, Ronald H. Perry Fonds, 82-016/2/8, Canoe Lake Camp Echoes 4, no. 3 (May 1931): 42; 4, no. 1 (February 1931): 40. On the host of methods for information gathering at Ahmek, see Dimock and Hendry, Camping and Character, 256-7, 263-88; Dimock and Statten, Talks to Counselors, 24-26.

49 TUA, Ronald H. Perry Papers, 82-016/2/8, Dimock, "Camping and Character Growth," 10-12. These laws received further elaboration in later editions of Camping and Character.

50 Dimock and Hendry, Camping and Character, 183. For discussion of other cases, see pages 165-201.

51 John R. Seeley, R. Alexander Sim, and Elizabeth W. Loosley, Crestwood Heights: A Study of the Culture of Suburban Life (Toronto: University of Toronto Press, 1956). The project was an attempt to explore the mental health of an entire neighbourhood, pseudonymously named "Crestwood Heights," but understood to refer to Toronto's exclusive Forest Hill neighbourhood. The study concluded that children from wealthy backgrounds were no better off, perhaps worse, in terms of mental health than other children. See also Pols, "Between the Laboratory and Life," 150-52; Low, "Hand that Rocked the Cradle," 50-53.

52 Dimock and Hendry, Camping and Character, 160.

53 Mary Northway, "What are the Camps Achieving," The Camping Magazine 9, no. 8 (1937).

54 Hamilton, Call of Algonquin, 168.

55 For discussions of parents see Dimock and Hendry, Camping and Character, 167, 183-4, 189. For the evolution of fatherly roles in these years, see Cynthia Comacchio, "A Postscript for Father': Defining a New Fatherhood in Interwar Canada," Canadian Historical Review 78, no. 3 (September 1997); and Robert Rutherdale, "Fatherhood and Masculine Domesticity During the Baby Boom: Consumption and Leisure in Advertising and Life Stories," in Edward-Andre Montigny and Anne Lorene Chambers, eds., Family Matters: Papers in Post-Confederation Canadian Family History (Toronto: Canadian Scholar's Press, 1988), 309-30; Chris Dummitt, "Finding a Place For Father: Selling the Barbecue in Postwar Canada," Journal of the Canadian Historical Association 9 (1998): 209-23.

56 Ibid., 169.

57 Donald Burry, "A History of the Taylor Statten Camps," (Unpublished Master of Science in Physical Education, University of Saskatchewan, 1985), 23.

58 Northway, Appraisal of Social Development, 18.

59 At least some difficult campers - who the camp claimed went on to be "first-class counsellors" - didn't seem to bear their camps any lasting animosity. Dimock and Hendry, Camping and Character, 200. Even while still a camper, one boy found the professional presence comforting, recalling warmly his sessions with the camp psychologist and other staff when left behind on a canoe trip in the 1950s. Jim Buchanan, interview by author, July 21, 2000.

60 TUA, Camp Pine Crest Fonds, 78-009/2/1, Camp Pine Crest, "Annual Report," 1940.

61 TUA, OCA Papers, 72-007/2/5, Toronto YWCA, "Camp Tapawingo," 1951.

62 TUA, OCA Papers, 78-006/25/29, “The Early Days of Camp On-Da-Da-Waks," 1950. 
63 TUA, Camp Pine Crest Fonds, 78-009/2/1, Camp Pine Crest, "Report on Lumberman Section, June 30 - August 25, 1949.”

64 TUA, Camp Pine Crest Fonds, 78-009/2/1, Rix Rogers, Camp Pine Crest, "Out-Trip Department - 1951 Report." Emphasis in original; TUA, Camp Pine Crest Fonds, 78-009/2/1, Camp Pine Crest, "Annual Report," 1940.

65 "Mother Fights for Health, Her Children get Holiday," TDS, August 5, 1931, 2.

66 FSATA, Minutes, Bolton Camp Committee, September 28, 1944.

67 Northway, "Socialization," 3. TUA, OCA Sound/Tape collection, 83-002/5/8, Barb Gilchrist, interview by Jack Pearse, November 6, 1986.

68 On falling enrolments at private camps, see Brian Back, Keewaydin Way; Donald Burry, "A History of the Taylor Statten Camps" (Unpublished Master of Science in Physical Education, University of Saskatchewan, 1985), 38-39, 39-40. On the pressure on fresh air camps, see "Star Fresh Air Fund Faces Certain Deficit Unless Cash Donated," TDS, August 27, 1931, 23; "Fresh Air Treasurer Needs $\$ 3000$ badly," TDS, August 31, 1931, 16; NWA, "New Interests at Bolton Camp in 1935," 1; FSATA, Minutes, Bolton Camp Committee, March 20, 1930.

69 On general labour shortages at camp, see TUA, OCA Papers, 78-006/1/1, Minutes, OCA Open Meeting, January 25, 1943. On the challenges of wartime fund-raising for fresh air camps, see "Fund Again To Give Holiday To City's Underprivileged," TDS, June 7, 1943; "First Holiday in 15 Years, Mother "Happy as a Lark"," TDS, August 31, 1944.

70 FSATA. "The Gateway to Health and Happiness: Bolton Camp Speaks Again, 1933," 15.

71 Dan Gibson to Donald Burry, December 20, 1984, quoted in Burry, "A History of the Taylor Statten Camps," 40.

72 "Just Two Weeks at Camp May Keep Boys Out of Jail," TDS, August 8, 1941, 16. For discussions of the panic over wartime delinquency, see Jeffrey Keshen, "Wartime Jitters Over Juveniles: Canada's Delinquency Scare and Its Consequences, 1939-1945," in Jeffrey Keshen, ed., Age of Contention: Readings in Canadian Social History, 1900-1945, ed. (Toronto: Harcourt Brace, 1997), 364-86. For discussions of working mothers and impacts on children in camp literature, see NWA, Bolton Camp Publicity Scrapbook, "Give Holiday to 1000 War Workers" Kiddies," TDS, June 2, 1942; FSATA, Minutes, Bolton Camp Committee, April 22, 1943. On juvenile delinquency in early Fresh Air Fund appeals, see "Frank Gets Chance to Become a Real Man," TDS, July 16, 1924, 1; "Denied Life's Comforts, Children Deserve Holiday," TDS, June 10, 1929, 19. For 1940s references, see "The Need is Great, Time Short," TDS, 20 July 20, 1940, 19; "21 Cramped up In 11 Small Rooms, 17 Children Need New Scene,” TDS, June 13, 1940, 21; "Once East End bad Boy Peter got camp help now pays way, 2 more," Toronto Daily Star, July 9, 1940, 17; "Let There Be No Broken Hearts," TDS, August 7, 1940, 17; "Only 2థ From Each of Us Would give 15,000 Holiday," TDS, June 30, 1947, 18.

73 Camp Fire, Fresh Air, "God's Gift To Boys," Judge sees Big Need," TDS, August 19, $1948,1$.

74 TUA, Adele and Harry Ebbs Papers, 80-014/1/8, Virginia T. Cobb to Mr. and Mrs. Taylor Statten, February 16, 1942 and response from Adele Ebbs, n.d.

75 Shirley Ford, interview by author, June 20, 2000.

76 Mary Northway, "Security Pegs for Campers," The Camping Magazine 14, no. 4 (April 1942): 3-7.

77 FSATA, "Bolton Summer Camp: Tomorrow Belongs to the Children," Brochure, 1949.

78 TUA, Adele and Harry Ebbs Papers, 80-014/1/8, "The Taylor Statten Camps," Brochure, c. 1950.

79 TUA, Adele and Harry Ebbs Papers, 80-014/1/8, "The Taylor Statten Camps," Brochure, c. 1950; UCA/VUA, Canadian Girls in Training Collection [CGIT], 85.095C - box 14 -file 1, CGIT Camp Manual, 1950, 44-45. 
80 TUA, Ontario Camp Leadership Centre, Bark Lake fonds, 98-012/1/1, "Bark Lake Canoeing Programme”, 1948; “Report on Canoe Trips," 1949.

81 TUA, OCA fonds, 72-007/2/7, Camp Winnebagoe, 1946 brochure.

82 TUA, Ontario Camp Leadership Centre, Bark Lake, fonds, 98-012/1/1, "Counselling Course," c. 1948.

83 UCA/VUA, CGIT Collection, 85.095C - box 42 - file 39, CGIT Camp Leaders" Manual, c. 1950s.

84 TUA, Camp Pine Crest Fonds, 78-009/2/1, Camp Pine Crest, “Director's Report,” 1951.

85 Northway, "Socialization," 3-5, 30.

86 "War or Peace - They Need Help," TDS, July 23, 1940, 17.

87 "Little Missionary Marnie, Example what Fresh Air Camp Does," TDS, August 9, 1947, 15.

88 Ontario Camp Leadership Centre [hereafter OCLC.], files in possession of Dorothy Walter, Toronto, Ontario, Copy of Address over C.K.E.Y. Broadcast, by Dr. J.G. Althouse, April 25, 1947, 3.

89 Hamilton, Call of Algonquin, 100.

90 Dimock and Hendry, Camping and Character, 5.

91 Dimock and Statten, Talks to Counselors, 33.

92 Margaret Rieder Paisley, "A Chat About Camps," The Torch 12, no. 2 (April/May 1936): 32.

93 TUA, OCA Papers, 72-007/2/6, Brochure, "Wabi-kon: A Summer Camp for Boys and Girls," c. 1950.

94 TUA, OCA Papers, 78-006/25/40, Mary Northway to Barry Lowes, March 9, 1964.

95 Archives of Ontario [hereafter, AO], Legislative Press Clippings, MS-755, Reel 86, "For Children's Welfare," Globe and Mail, July 14, 1944.

96 Dewey's thoughts on education are summed up in The School and Society (1900) and Democracy and Education (1916). For discussions of experimentation with progressive education in Canadian schools, see Gleason, "Psychology in Postwar Schools," chapter 6 in Normalizing the Ideal, 119-39; R. S. Patterson, "The Canadian Experience with Progressive Education," and Eamonn Callan, "John Dewey and the Two Faces of Progressive Education," both in Canadian Education: Historical Themes and Contemporary Issues, ed. E. Brian Titley (Calgary: Detselig Enterprises, Ltd., 1990), 95-110; Neil Sutherland, "The Triumph of "Formalism": Elementary Schooling in Vancouver from the 1920's to the 1960's," B.C. Studies 69-70 (Spring/Summer 1986): 175-210; Robert Stamp, "Education for Democratic Citizenship, The Schools of Ontario, 1876-1976 (Toronto: University of Toronto Press, 1982), 164-82; Jean Mann, "G.M. Weir and H.B. King: Progressive Education or Education for the Progressive State?" in Schooling and Society in Twentieth-Century British Columbia, ed. J. Donald Wilson and David C. Jones (Calgary: Detselig Enterprises Ltd., 1980), 91-11; see also Sutherland, chapters ten to thirteen in Children in English-Canadian Society. For discussion of progressive education in the American context, see Cohen, chapter five in Challenging Orthodoxies.

97 TUA, OCA Papers, 98-019/13/10, Taylor Statten, "Developing the Program on a Group Basis," Address to the Conference of the Pacific Camping Association, March 16-19, 1939.

98 TUA, Northway Family Fonds - Additions, 90-016/1/35, copy of Mary Northway, "Camping in Canada," Canadian Geographical Journal 20, no. 6 (1940): 333.

99 FSATA, "Bolton Summer Camp," First Appeal brochure, 1947.

100 TUA, Camp Pine Crest Fonds, 78-009/2/1, Camp Pine Crest, Brochure template, c. 1942.

101 On the physical education of girls, the opening up of new programmes and debates over competition, see Veronica Strong-Boag, The New Day Recalled: Lives of Girls and Women 
in English Canada, 1919-1939 (Toronto: Copp Clark Pittman, 1988): 31-32; Helen Lenskyj, "Femininity First: Sport and Physical Education for Ontario Girls, 18901930," Canadian Journal of History of Sport 13, no. 2 (December 1982): 4-17; Helen Lenskyj, "Training for "True Womanhood": Physical Education for Girls in Ontario Schools, 1890-1920," Historical Studies in Education 1, no. 2 (Fall 1990): 205-23; M. Ann Hall, "Rarely Have We Asked Why: Reflections on Canadian Women's Experience in Sport," Atlantis 6, no. 1 (1980): 51-60. It should be noted that camp programmes for girls and boys were never identical. Girls were always treated more carefully at camp, though, especially at canoe-tripping camps they were also exposed to numerous challenges and were given the chance to hone their less traditionally "feminine" skills. See Author, 2003. See also Lathrop, "'Strap an Axe to Your Belt"; Susan L. Forbes, "Nothing But a Rag Between You and the Sky". For the treatment of girls at American camps see Paris, "Children's Nature"; Miller, "Girls in Nature/The Nature of Girls."

102 Susan Morgan recalls being chosen "by secret ballot" as a "Colour War" captain at the end of camp season as "the ultimate affirming experience ... I'm sure people who get elected to Parliament don't feel better than I [did]." Susan Morgan, quoted in Sherman, "Girls of Summer," 103. On the "Worthy Woodsman" and the "Pine Tree" awards, see Hamilton, Call of Algonquin, 117; 144. On making record-time canoe trips, see Elizabeth Shapiro, email interview by author, February 17, 2001. Similarly remembering "a rough, rough, trip" along the Mattawa and Ottawa Rivers in the 1920s, Mary Northway explained, "We were always known as the girls who had gone to Mattawa and back." TUA, OCA Sound/Tape Collection, 83-002/2/5, Mary Northway, Interview by Cathy Stuart and Warren Anderson, January 21, 1975.

103 Statten, "Developing the Program on a Group Basis."

104 Hamilton, Call of Algonquin, 20.

105 TUA, Camp Pine Crest Fonds, 78-009/2/1, Camp Pine Crest, "Annual report," 1940.

106 Dimock and Statten, Talks to Counselors, 39. Similar statements were made at other camps: "swimming instruction," according to a Bolton report, "involved a great deal more than the skill of swimming. The qualities of courage, perseverance and selfconfidence are all part of the learning process." FSATA, "Bolton Camp: Report of Operation, 1937," 3.

107 Statten, Talks to Counsellors, 8.

108 TUA, Camp Pine Crest Fonds, 78-009/2/1, "Interim Report to the Camp Pine Crest Commitee," September 22, 1952.

109 Dimock and Statten, Talks to Counselors, 52.

110 TUA, Ronald H. Perry Fonds, 82-016/2/8, "Camping and Character" Canoe Lake Camp Echoes 3, 1 (May 1930): 17.

111 Northway, "Camping in Canada," 330.

112 "Pale-Faced City Tikes Taught Indian Lore by Expert Woodsmen," TDS, Wednesday, June 5, 1950, 25.

113 TUA, OCA Papers, 72-007/2/5, Toronto YWCA, “Camp Tapawingo," 1951.

114 TUA, Northway Family Fonds - Additions, 90-016/1/25, Mary Northway, "Sustaining Interests," The Camping Magazine 11, no. 9 (1939).

115 Hamilton, Call of Algonquin, 57.

116 Dimock and Statten, Talks to Counselors, 27, counsellor duties, 27-34. To help ensure a supply of staff with this level of skills, efforts were made towards establishing a standardized system of "teacher training." In 1925, the Margaret Eaton School of Physical Education in Toronto offered one of the first institution-based courses in counsellor training. In 1941 it merged with the University of Toronto's to form the School of Physical and Health Education. Hamilton, Call of Algonquin, 169-170. Underscoring its own belief in the educational value of camping, in 1949, the provincial government set up its own counsellor-training camp at Bark Lake in Haliburton. OCA, Ontario Camp Bulletin Edition 2, 1946; TUA, Adele and Harry Ebbs Papers, 
80-014/1/5, 'season of 1947 - Programme of Staff Training,” 1947; OCA Papers, 72-007/2/8, Camp Responses to Ontario Camping Association, "Confidential Camp Counsellor Survey" 1952; Hamilton, Call of Algonquin, 86, 89.

117 FSATA, Bolton Camp Publicity Scrapbook, "U.S. Visitor Outlines Vast Camp Scheme," TDS, April 12, 1937.

118 Dimock and Hendry, Camping and Character, 4.

119 Sutherland, "Triumph of "Formalism"; For other accounts of the failure of progressive education, see also Robert Stamp, "Education for Democratic Citizenship"; Mann, "G.M. Weir and H.B. King"; Patterson, "Canadian Experience with Progressive Education"; Callan, "John Dewey”; Tomkins, A Common Countenance; Gleason, Normalizing the Ideal, 119-39.

120 Paul Axelrod, "Beyond the Progressive Education Debate: A Profile of Toronto Schooling in the 1950's," Historical Studies in Education 17, no. 2 (2005): 227-41.

121 "City Mission Carries on Fresh Air Work 46 Years," TDS, July 16, 1940; “Every \$7.50 You Send In Sends a Poor Child Away," TDS, July 29, 1925, 1; "Fresh Air Fund Donations buy Shares In Happiness,” TDS, June 5, 1926, 17.

122 "Children Get New Outlook By Miracle of Fresh Air," TDS, June 6, 1949, 5.

123 "Lions Party At Beausoleil Camp Closes Spot Where Lads Had Fun," TDS, August 20, 1940, 9.

124 Hamilton, Call of Algonquin, 87.

125 Ibid., 135.

126 TUA, Ronald H. Perry Fonds, 82-016/3/5, Weekly Canoes Paper 1, 3 (August 5, 1948): 1.

127 TUA, Ronald H. Perry Fonds, 82-016/3/3, "Taylor Statten Camps, Campcraft and Out Trips," June 1948; “Taylor Statten Camps - Canoe Trip Report," n.d.

128 Dimock and Hendry, Camping and Character, 156, 279-80

129 TUA, Ronald H. Perry Papers, 82-016/3/2, "1938 Final Report - Canoeing."

130 TUA, Camp Pine Crest Fonds, 78-009/2/1, Camp Pine Crest, "Report on Lumberman Section, June 30 - August 25, 1949”; TUA, Camp Pine Crest Fonds, 78-009/2/1, Camp Pine Crest, "Director's Report," 1949.

131 n.a., Fires of Friendship: Eighty Years of the Taylor Statten Camps (Taylor Statten Camps: 2001), 29. This was also the practice at Glen Bernard, and, more than likely, other camps as well. Shirley Ford, interview by author, June 20, 2000.

132 Shirley Ford, interview by author, June 20, 2000.

133 Mary Murphy, interview by author, June 7, 2000.

134 On the danger and frequency of "crushes" and same-sex affection at camp, see Taylor Statten Camps, Talks to Counsellors, 1928, 2; Dimock and Statten, Talks to Counselors, 31; TUA, OCA Papers, 98-019/13/10, "Notes from the Course in Camp Education, Margaret Eaton School," 10 February - 17 March 1937, 2; TUA, Northway Family Fonds - Additions, 90-016/1/25, Mary Northway, "What are the Camps Achieving," The Camping Magazine 9, 8, (1937).

135 Dimock and Hendry, Camping and Character, 180.

136 Ruth-Ellen Soles, quoted in Sherman, "Girls of Summer," 102.

137 Paris, "Children's Nature," 164. See also Paris, "Please Let Me Come Home': Homesickness and Family Ties at Early-Twentieth-Century Summer Camps" in The American Child: A Cultural Studies Reader, eds. Caroline Levander and Carol Singley (New Brunswick, N.J.: Rutgers University Press, 2003). The 1957 study was carried out by Dr. Taylor Statten, psychiatrist and son of the well-known Taylor Statten who founded Camp Ahmek. TUA, OCA fonds, 72-007/5/16, Dr. Taylor Statten, "Homesickness," April and June 1957.

138 Northway, Appraisal of Social Development. 55.

139 TUA, Adele and Harry Ebbs Papers, 80-014/1/5, "Season of 1947 - Programme of Staff Training," 1947. 
140 Northway, "Security Pegs."

141 Norman Gulko, interview by author, June 16, 2000; Bert Danson, interview by author, June 12, 2000; Shirley Ford, interview by author, June 20, 2000.

142 Statten, "Developing the Program on a Group Basis." For Paris' thoughts on camp pranks, see Paris, "Children's Nature," 169-71.

143 TUA, Camp Pine Crest Fonds, 78-009/2/1, Camp Pine Crest, "Annual Report," 1940.

144 Sherman, "Girls of Summer," 101.

145 Joan Moses, interview by author, July 26, 2000.

146 Merle S. Storey, quoted in Fires of Friendship, 37.

147 Douglas Creelman, interview by author, June 23, 2000, Toronto.

148 TUA, OCA Sound/Tape Collection, 83-002/5/24, Mary Northway, interview by Jocelyn Palm, November 17, 1981.

149 Snedden, quoted in Dimock and Hendry, Camping and Character, 328. 